\title{
ELS “CLAMORES" DE SANT CUGAT \\ CONTRA EL FILL DEL GRAN SENESCAL I ALTRES EPISODIS DE TERRORISME NOBILIARI (1161-1162)
}

\author{
PERE BENITO I MONCLÚS \\ Universitat de Barcelona
}

\begin{abstract}
SUMARI
1. Una querimònia desconeguda.- 2. Guillem II de Montcada: l'assalt del mas Saltells i altres episodis de la "persecutio".- 3. Guillem III de Sant Martí: les dominicatures de Castelldefels i Torres Beces.- 4. La penyora de Gallecs i el plet sobre el castell de Sant Vicenç de Calders.- 5. El retorn de Guillem de Montcada: les vexacions a la comunitat monàstica.- 6. Nova aproximació a la datació del document i resolució dels conflictes.- 7. El document.
\end{abstract}

\section{UNA QUERIMÒNIA DESCONEGUDA}

Entre els pergamins sense inventariar de la secció de Monacals de l'Arxiu de la Corona d'Aragó figura una querimònia procedent de l'antic arxiu de Sant Cugat del Vallès fins fa poc desconeguda ${ }^{2}$. La relació de queixes

${ }^{1}$ Abreviatures emprades: $\mathrm{ACA}=$ Arxiu de la Corona d'Aragó; $\mathrm{BC}=$ Biblioteca de Catalunya; $\mathrm{CR}$ = "Catalunya Romànica", 25 vols., Barcelona, Fundació Enciclopèdia Catalana, 1984-1996; CSC = Cartulari de Sant Cugat del Vallès; LFM = Francisco MIQUEL RosELL (ed.), "Liber Feudorum Maior", Barcelona, CSIC, 1945-1947; RIUS = José RIUS SERRA (ed.), Cartulario de Sant Cugat del Vallés, 3 vols., Barcelona, CSIC, 1945-1947; s.d. = sense data.

${ }^{2}$ Aquesta querimònia no apareix en el catàleg que l'arxiver Ragà elaborà l'any 1917 , el qual recull, per ordre cronològic, la documentació de procedència monàstica anterior al 1300 Possiblement fou exclosa de la catalogació inicial de la documentació monàstica degut a la manca 
(clamores), adreçada per l'abat i els monjos de Sant Cugat al comte de Barcelona, relata els actes de violència i de pillatge perpetrats contra els homes i les propietats del monestir per diversos nobles, entre els quals ocupa un lloc destacat Guillem II de Montcada, fill gran i hereu del senescal Guillem Ramon II.

Tal i com feren els homes del comte, víctimes per la mateixa època de l'arbitrarietat dels castlans i batlles que exercien poders de justícia sobre ells $^{3}$, l'abat i els monjos de Sant Cugat acudeixen al tribunal comtal per a clamar justícia. El paral·lelisme és evident: entre els nobles denunciats a la querimònia figuren alguns dels homes de màxima confiança del comte, feudataris o vassalls directes seus. Cal tenir en compte, d'altra banda, que Sant Cugat és un monestir estretament vinculat al poder comtal ${ }^{4}$, que, tal i com recorda la mateixa querimònia, fou dotat pels comtes de Barcelona ${ }^{5}$, els

de datació i d'estructura diplomàtica puix que figura al costat d'alguns capbreus indatats entre els pergamins que encara romanen per inventariar. Agraeixo a Albert Torra Pérez d'haver-me facilitat la consulta dels pergamins més antics d'aquest fons en procés de catalogació.

${ }^{3}$ La veu dels homes del comte fou recollida per escrit en memorials de queixes, els quals, per la seva càrrega política, es conservaren posteriorment dins de l'arxiu reial. Constitutiexen un grup coherent d'una quinzena de documents indatats, anònims i originals, datables del període 1145 1190 , durant els regnats de Ramon Berenguer IV i a Alfons I. Segons Thomas BISSON, The Crisis of the Catalonian Franchises (1150-1200), "Estudi General", 5-6 (1985-1986), pp. 153-172, i Tormented voices. Power, Crisis, and Humanity in Rural Catalonia. 1140-1200, Cambridge-Massachusetts, Harvard University Press, 1998, pp. 68-115, aquestes querimònies reflecteixen a mitjan segle XII una segona crisi de les franqueses catalanes com a conseqüència d'una crisi en les relacions entre els representants del poder públic i els nobles, rèplica del que hauria esdevingut de manera més general i virolenta el segle anterior. Es probable, segons l'autor, que aquestes fossin comunitats lliures, de franquesa, del mateix tipus que havien sorgit a les ciutats en un ordre públic protegit pels comtes, ordre que havia sucumbit amb la instauració de la "senyoria banal" a començament del segle XI

${ }^{4} \mathrm{~A}$ les darreries del segle XI, els comtes de Barcelona intervingueren directament en la vida del monestir. Ramon Berenguer II agregà Sant Cugat a l'abadia provençal de Sant Ponç de Tomeres, amb l'objectiu d'introduir-hi la Reforma Gregoriana. L'any 1089 l'abat Frotard de Tomeres ocupà el monestir i n'expulsà els monjos. Dos anys més tard, Ramon Berenguer III, amb l'aprobació del papa Urbà II, condemnà la intervenció de Tomeres i obligà Frotard a restituir el monestir a l'antiga comunitat. Els anys 1097, 1098 i 1099 confirmà i donà a Sant Cugat els cenobis de Santa Cecília de Montserrat, Sant Llorenç del Munt amb la Llacuna i Sant Salvador de Breda, i també Sant Pau del Camp, Santa Maria de Fontrúbia i Sant Pere de Clarà, que foren convertits en priorats depenents. Sant Cugat esdevenia així, per decisió comtal, el centre de la primera congregació de monestirs catalans (Anscari MUNDÓ, Moissac, Cluny et les mouvements monastiques de l'Est des Pyrénées du X $X^{e}$ au XII siècle, "Annales du Midi", LXXV [1963], pp. 566-568).

${ }^{5}$ Els comtes-reis realitzaren nombroses donacions i, seguint la tradició dels monarques francs, expediren cartes de confirmació de béns. El 4 de setembre de 1130 Ramon Berenguer III donà a l'abat Roland les franqueses d'Aiguallonga i de Mesquidelles (ACA, CSC, f. 13, núm. 22, RIUS, III, doc. 903, pp. 93-94). Un any més tard, el 19 de juliol, el comte deixà al monestir les franqueses que tenia dins l'honor del monestir, juntament amb el Montmajor al damunt de Caldes 
quals hi exerciren directament la seva guarda i batllia ${ }^{6}$. Per a l'abat i els monjos de Sant Cugat el comte era, sense cap mena de dubte, el millor jutge $i$ àrbitre en aquest conflicte.

Encara avui resulta en bona mesura enigmàtic per què durant els darrers anys del govern de Ramon Berenguer IV i durant el regnat d'Alfons el Cast nombroses querimònies es posaren per escrit, donant lloc a documents independents, desprovistos de validesa diplomàtica, que foren preservats durant segles dins l'arxiu reial, dins d'arxius monàstics o pagesos ${ }^{7}$, tenint en compte la funció de la querimònia dins la mecànica processal ${ }^{8}$.

Thomas Bisson considera la producció dels memorials de queixes elevats pels homes del comte contra els castlans i administradors dels seus dominis durant els anys centrals del segle XII en el marc d'una campanya política de reforma administrativa més àmplia, de la qual formarien part, també, la redacció del capbreu de 1151 i la institucionalització posterior d'una comptabilitat escrita regular de les batllies. Ramon Berenguer IV hauria intentat restablir la seva autoritat per procediments judicials durant els anys immediatament posteriors a la conquesta de la Catalunya Nova. D'acord amb aquesta hipòtesi, els oficials del comte haurien tingut un paper actiu en la gènesi d'aquests memorials i dels processos judicials que se'n derivaren.

(ACA, Ramon Berenguer IV, perg. 6. Rius, III, doc. 911, p. 100). El 13 de juliol del mateix any (1131) el comte confirmà al monestir l'honor de Montmajor que el seu pare havia llegat al monestir. Rius, III, doc. 914, pp. 102-103. L'any 1174 Alfons I confirmà a l'abat Guillem diversos honors que havien estat donats al monestir per dotació dels seus fills com a monjos, situats al comtat de Manresa, al terme del castell de Tàrrega (ACA, CSC, f. 209, núm. 651. RIUS, III, doc. 1098, p. 255). Els privilegis i donacions atorgats pels comtes al monestir i tots els dominis i propietats foren confirmats per Jaume I l'any 1234 (ACA, CSC, f. 412, doc. 1202; RIUS, III, pp. 431-434, núm. 1320).

${ }^{6}$ Vegeu més avall, pp. 872-873.

${ }^{7}$ El mas Pins d'Argentona, centre de batllia dels dominis del priorat de Sant Marçal del Montseny al Maresme, ha conservat un petit arxiu patrimonial, el document més antic del qual és una querimònia que l'any 1179 els homes de Sant Marçal, víctimes de les accions de Ramon de Cabanyes, castlà del castell de Sant Vicenç, adreçaren al primicer de la seu de Barcelona, acompanyada d'una relació dels danys soferts i d'una valoració econòmica dels mateixos. Sobre aquest document, vegeu el nostre estudi Violències feudals $i$ diferenciació social pagesa. Els homes de Sant Marçal del Montseny a Vilassar i Argentona a la segona meitat del segle XII, "Fulls del Museu Arxiu de Santa Maria", 37 (Mataró, abril, 1990), pp. 15-27.

${ }^{8}$ Les querimònies, que precedien els actes dels judicis, eren en principi orals. Només a partir de mitjan segle XI algunes d'aquestes querimònies es posaren per escrit en pergamins 0 , excepcionalment, foren incloses dins dels actes dels mateixos judicis. Cf. Blanca Garí, Las "querimoniae", pp. 7-49; "Haec sunt rancuras...". Análisis de una querimonia catalana del siglo XI, "Homenaje al profesor Juan Torres Fontes", Murcia, Universidad de Murcia - Academia Alfonso X el Sabio, 1987, vol. 1, pp. 605-606. 
Posteriorment, per la seva especial significació política ${ }^{9}$ aquests textos haurien estat preservats dins l'arxiu reial, mentre hom destruïa la resta de la documentació judicial. Algú, probablement Ramon de Caldes durant els anys 1178-1196 - apunta Bisson-, dugué a terme aquesta sel·lecció ${ }^{10}$.

Pel marcat paral·lelisme que presenten amb les querimònies comtals, els clamores de Sant Cugat podrien, indirectament, tenir relació amb l'intent de Ramon Berenguer IV de limitar l'autoritarisme dels magnats i restablir la pau territorial per procediments judicials. Els oficials del comte haurien encoratjat o, potser induït directament, els monjos de Sant Cugat a elevar les seves queixes al tribunal comtal en demanda de justícia. Caldrà afegir només que la querimònia de Sant Cugat involucra algunes de les famílies nobles més poderoses de l'època al comtat de Barcelona.

Una circumstància separa, però, els clamores de Sant Cugat de les querimònies comtals. El memorial de Sant Cugat, adreçat a Ramon Berenguer IV, no es troba avui entre els pergamins supervivents de l'arxiu dels comtes de Barcelona, sinó entre la documentació pròpia de l'abadia. Aquesta dada és més significativa encara si tenim en compte que l'arxiu de Sant Cugat, un dels arxius monàstics que ens han arribat amb major grau d'integritat, ha conservat un volum important de documentació judicial dels segles XII-XIII, una part de la qual, per la seva importància, fou copiada en el Cartulari. Molts d'aquests actes i notícies de judicis, sentències i definicions fan referència a la presentació prèvia de querimònies ${ }^{11}$, però només aquesta querimònia s'ha conservat com a document independent. Igual que les querimònies comtals, els greuges de Sant Cugat constitueixen una singularitat documental dins l'arxiu monàstic.

\footnotetext{
"Blanca GARÍ, Las "querimoniae", p. 44, ha destacat l'element diferencial que representen les querimònies comtals per oposició a les d'origen feudal: "El mercado, la via pública, la justicia sobre sus tierras... tres quejas que coinciden en resaltar la imagen pública de la potestas condal. (...) Esa sí es una diferencia fundamental de las querimoniae condales, la existencia de un matiz de soberanía sobre lo público, ausente de cualquiera de los inventarios de quejas que entre 1131 y 1178 redactan los feudales,..." Bisson, The Crisis..., p. 172, per la seva banda, conclou: "The querimoniae from the franchises resounded in comital circles with an incipient ideology of regalian principate."

${ }^{10}$ Bisson, Tormented voices, p. 76.

"Josep Maria SALRACH, "Multa placita et contenciones": conflictos de los siglos X-XII en el Cartulario de Sant Cugat del Vallés, Colloque International "Les origines de la Féodalité", Talence, Maison des Pays Ibériques, 1993.
} 
No podem aspirar a explicar satisfactòriament aquest extrem, però és possible que en moments posteriors aquesta querimònia jugués algun paper en l'afirmació de la independència jurisdiccional del monestir i dels seus homes respecte del poder baronial. La querimònia recordava l'especial vinculació de la institució al poder comtal i la supremacia jurisdiccional del comte-rei sobre tots els dominis del monestir, inclosos els enclavats en territoris de justícia baronial. La querimònia de Sant Cugat fou produïda i, sobretot, conservada deliberadament més pel que significava que per al que serví.

Al marge de la seva significació històrica, la querimònia de Sant Cugat presenta, com a font, unes característiques específiques que l'allunyen de les querimònies comtals $i$, en general, de la resta de querimònies conegudes. És, en primer lloc, una de les relacions de queixes més extenses i detallades que ens han arribat. En segon lloc, i aquesta és sens dubte la seva originalitat, es tracta d'una producció culte, elaborada per l'escriptori monàstic, redactada en un llatí correcte, d'un estil acurat ${ }^{12} i$, el que és remarcable, conté nombrosos referents temporals destinats a atorgar credibilitat a la declaració dels monjos. L'estil narratiu dels clamores de Sant Cugat contrasta amb l'aspecte comptable que presenten algunes de les querimònies coetànies elevades al comte per les comunitats pageses, l'objectiu de les quals era obtenir el redreçament dels danys soferts ${ }^{13}$. La querimònia de Sant Cugant se'ns presenta, i devia presentar-se als ulls dels monjos, pel damunt de tot, com un "memorial", i aquest valor afegit degué ser, a partir d'un determinat moment, un argument de pes per a no destruir-la. Al llarg dels més de sis segles d'història de l'arxiu santcugatenc, més d'un monjoarxiver degué considerar que aquesta extravagància documental havia de ser preservada.

La informació de la querimònia permet, d'antuvi, aproximar-nos al moment de la seva redacció amb una precisió gens habitual en aquest tipus de documents indatats. La querimònia aludeix a la sentència pronunciada pel

\footnotetext{
${ }^{12} \mathrm{En}$ un moment en què, paradoxalment, comencen a aflorar en les querimònies populars, elevades per comunitats rurals, expressions vernaculars que recorden el seu caràcter oral. L'exemple per antonomàssia és la querimònia Zo són clams adreçada pels homes de Sant Pere de Graudescales de Navès (Solonès) al bisbe i al capítol d'Urgell, redactada íntegrament en català. Cf. Pere PUjOl I TUBAU, Documents en vulgar dels segles XI, XII $i$ XIII procedents del bisbat d'Urgell, "Biblioteca Filològica de l'Institut de Llengua Catalana", Barcelona, 1913, pp. 13-14 Maria BROSSA, Estudi lingüistic d'un document català del segle XII ("Zo són clams") de l'Arxiu de la Seu d'Urgell (segles XI-XII), "Urgellia", 6 (1983), pp. 335-359.

${ }^{13}$ BISson, The Crisis, pp. 155-157, Tormented voices, p. 77.
} 
jutge Borrell de Girona en la causa que enfrontava l'abat Ramon, d'una banda, i Arnau de Benages i Berenguer d'Ollers, de l'altra, sobre el castell de Sant Vicenç de Calders. Aquesta sentència, dictada el 2 d'octubre de 1160, fou copiada al Cartulari de Sant Cugat ${ }^{14}$. La redacció del text ha des situar-se entre aquesta data i el 6 d'agost de 1162, data de la mort de Ramon Berenguer $\mathrm{IV}^{15}$, comte al qual s'adreça la querimònia, en època de l'abat Ramon de Sentmenat (1151-1173). Aquesta datació és coherent amb els personatges citats a la querimònia, la presència dels quals pot ser rastrejada en la documentació monàstica dels anys centrals del segle XII.

Tot i que els monjos redactors conferiren al document, que fins aquí hem anomenat, en singular, querimònia, una marcada unitat, aquest està constituït, en realitat, per cinc parts corresponents a cinc relacions de queixes textualment diferenciades ${ }^{16}$ que involucren personatges diferents i que relaten uns fets esdevinguts en temps i llocs diferents.

\section{GUILLEM II DE MONTCADA:}

\section{L'ASSALT DEL MAS SALTELLS I ALTRES EPISODIS DE LA PERSECUTIO}

La primera part, la més extensa de les cinc, comprèn els clamores de Sant Cugat contra Guillem II de Montcada, fill gran de Guillem Ramon II (c. 1090-1173), el Gran Senescal de la historiografia romàntica ${ }^{17}$, i de Beatriu (c. 1100-1150), i senyor de Montcada i de $\operatorname{Vic}^{18}$, pels actes de violència i de vandalisme perpetrats contra els dominis del monestir al Vallès, als termes dels castells de Cerdanyola i de Montcada.

${ }^{14} \mathrm{ACA}$, CSC, f. 104, doc. 350, Rius, III, p. 205, núm. 1035.

${ }^{15}$ Jordi VENTURA, Alfons el Cast. El primer comte-rei, Barcelona, Aedos, 1961, p. 66.

${ }^{16}$ Cadascuna de les cinc querimònies correspon en el document a un paràgraf, precedit per una lletra capital i acabat amb punt i a cap.

${ }^{17}$ Cf. Antonio Rubio y Lluch, D. Guillermo Ramón de Montcada; Gran senescal de Cataluña, Barcelona, 1886, p. 5.

${ }^{18}$ Segons Shideler, Guillem II de Montcada va viure aproximadament entre 1120 i 1172; devia, doncs, tenir uns 40 anys a l'època de la querimònia. Guillem heretà de la seva mare Beatriu el patrimoni dels Montcada, que incloïa els castells i senyories de Montcada i de Vic. Casà amb Maria, vescomtessa de Bearn (abans del 1164). No va arribar a heretar la senescalia, la qual, a la mort del seu pare l'any 1173 , passà amb el patrimoni català dels Montcada al seu germà Ramon. Cf. John C. SHIDELER, A Medieval Catalan Noble Familiy. The Montcadas (10001230), Berkeley-Los Ángeles, University of California-Press, 1983, pp. 109-110, 115 i 118. 
La relació de queixes pren la forma d'un diari en el qual es relaten tot un seguit d'accions protagonitzades pel mateix Guillem, acompanyat de la seva comitiva d'homes armats, pel seu batlle Berenguer de Saltells i, en una ocasió, per manament d'aquest, per un personatge anomenat Bernat de Castlari ${ }^{19}$. Es relaten fets esdevinguts en almenys dotze dies diferents, en quatre dels quals hom precisa el moment de l'any en relació al calendari litúrgic: per Sant Pau (11-XII), el dissabte abans de Nadal ${ }^{20}$, per Sant Esteve (26-XII) i el dia dels Innocents (28-XII). Sembla que, en general, existeix una seqüència entre els episodis relatats. El primer i el quart degueren tenir lloc després de les collites de cereals d'estiu, puix que impliquen robatoris de blat, ordi i espelta, ja sigui directament o exigint-ho com a pagament per la redempció d'un home. Per la seva banda, els episodis datats, exceptuant el dels Innocents, estan ordenats cronològicament i ocupen el vuitè, onzè i dotzè lloc de la relació. Sembla, doncs, que els fets descrits en els clamores contra Guillem de Montcada tingueren lloc en un mateix any, entre les collites de cereals d'estiu i la diada de Sant Esteve.

Els atacs de Guillem de Montcada i del seu batlle Berenguer de Saltells tenen com a objectiu principal el mas Saltells, escenari de sis dels dotze episodis relatats en la querimònia. Aquest alou de Sant Cugat, enclavat dins del terme de l'antic castell de Sant Marçal o de Cerdanyola ${ }^{21}$, domini dels

${ }^{19}$ Desconeixem la condició de Bernat de Castlarí (o Castlaril) i la seva relació amb Guillem de Montcada i el batlle Berenguer de Saltells. Bernat de Castclarí és documentat l'any 1159 quan rep de mans de l'abat Bernat de Sant Llorenc del Munt un mas situat a la parròquia de Santa Maria de Caldes, terme de Sentmenat, al lloc Mascaró, per a tenir-lo ell i els seus descendents pel monestir, i la meitat del mas Olzet, situat a la parròquia de Sant Esteve de Castellar, per a tenir-lo només mentre visqui (ACA, Monacals, Sant Llorenc del Munt, perg. 296). Posteriorment apareix en diversos documents de Sant Cugat els anys 1163-1164 (ACA, CSC, f. 47, doc. 157; RIUS, III, pp. 214-215, núm. 1049), 1175 (ACA, CSC, f. 387, doc. 1125, RIUS, III, pp. 258-260, núm. 1102) i 1176 (ACA, CSC, f. 30-31, docs. 91 i 92 ; RIUS, III, pp. 262-264, núms. 1107 1108).

${ }^{20}$ Segurament el 23 de desembre. Vegeu més avall, p. 874.

${ }^{21}$ El topònim Saltells designa en la documentació de Sant Cugat de finals del segle $\mathrm{X}$ i del segle XI la franja de terres situada entre el Riusec i el Ripoll fins a la confluència d'ambdós rius, dins dels termes de Cerdanyola i de Ripollet. Tres documents dels anys 1054, 1059 (ACA, CSC, f. 71, docs. 277 i 278, RIUS, II, pp. 270-271, núm. 603, i pp. 283-284, núm. 617), 1079 (ACA, CSC, f. 68, doc. 266, RiUs, II, pp. 359-360, núm. 696) il1110 (ACA, Monacals, pergs. 404 405, RiUS, III, p. 13, núm. 811) fan referència al riu o riera Saltells, que cal identificar amb el Riusec. Segons Salvador CARDús, Un Nadal tacat de sang, Barcelona, 1961, p. 39, el mas Saltells s'alçava a migdia-ponent del Riusec o Saltells, en el lloc que en el moment que escrivia aquest autor ocupaven les cases Serrra-Parera i Cordelles de Cerdanyola, i comprenia una gran extensió de terres en les quals hi havia edificats diversos masos. Les seves terres eren creuades pel camí que anava de Barcelona a Terrassa. Vegeu mapa 2. 
Montcada $^{22}$, és l'objecte d'una de les precàries més antigues conservades a l'arxiu monàstic que impliquen la cessió de tinença hereditària a perpetuïtat. Es tracta de la donació que l'any 1132 fa l'abat Ermengol a Berenguer Arnau de la seva femina, Adelaida de Saltells, perquè la tingui com a muller juntament amb el mas ${ }^{23}$. Tot i que, excepcionalment, l'acte pren la forma d'una donació personal en ocasió de noces, la qual cosa posa a primer pla el vincle personal que uneix Adelaida de Saltells amb el monestir, en realitat es tracta d'una precària o acte d'establiment del mas Saltells, en el qual s'estipulen les obligacions del nouvingut en el mas, Berenguer Arnau, el futur marit d'Adelaida, i dels seus descendents. A diferència de la majoria de precàries de masos que afloren en els arxius eclesiàstics pels mateixos anys, aquestes obligacions no són únicament econòmiques, sinó també de caràcter defensiu. Berenguer Arnau haurà de recollir a la torre el fill de Pere Olivà quan a aquest li sigui necessari per a salvar el seu cos i les seves $\operatorname{coses}^{24}$. La donació ens presenta el mas Saltells com un mas important, fortificat, en el qual hauran de conviure dos homes (Berenguer Arnau i el fill de Pere Olivà $)^{25}$, la relació dels quals no s'explicita. I el que és més rellevant, la proximitat dels Montcada és contemplada com una amenaça pels monjos de Sant Cugat. L'abat prohibeix a Berenguer Arnau de donar de menjar als senyors de Montcada i d'hostatjar-los ${ }^{26}$. Aquesta prevenció és un indici que ja en aquest moment aquest enclau territorial era l'epicentre d'un conflicte de

${ }^{22} \mathrm{El}$ castell de Sant Marçal o de Cerdanyola devia formar part del paquet de feus que el 7 de juliol de 1136 el senescal Guillem Ramon II rebé de mans de Ramon Berenguer III, tot i que no consta en la relació de castells infeudats, probablement perquè devia considerar-se com un apèndix o quadra del veí castell de Montcada (LFM, I, pp. 480-482, docs. 457 i 458). L'acord de divorci de Guillem Ramon II i Beatriu de Montcada, signat aquell mateix dia, estableix que en cas que Beatriu es tornés a casar tingui mentre visqui la meitat de la dominicatura i de la staticam de Sant Marçal, i que després del seu òbit passi als fills seus i de Guillem Ramon II (LFM, I, pp. 331-332, doc. 307). SHIDELER, The Montcadas, pp. 91-92.

${ }^{23} \mathrm{ACA}$, Monacals, Sant Cugat del Vallès, perg. 470 (còpia feta per Alerand, monjo), RIUS, III, p. 108, núm. 921.

24، Turris vero que ibi est, habeas tu Berengario cum uxore tua et filii vestri, unus post alium, et si necese fuerit predicto filio Petri Olibe, recolligas eum ad salvandum corpus suum et ad suum avere in ipsa turre".

${ }^{25}$ Podria tractar-se del Pere Olibà que l'any 1124 rebé de l'abat Roland la meitat d'un molí que havia construït en alou del monestir a la parròquia de Sant Esteve de Breda, a Parets, als prats i a la riera de Tenes, unes illes i uns prats, juntament amb Berenguer Guadall, que rebé l'altra meitat (ACA, CSC, f. 366, doc. 1059. Rius, III, pp. 70-71, doc. 876).

26“....et non dones ad comedendum in ipso manso de Saltels senioribus Montischatani neque recipies eos ad ospicium". 
drets entre els Montcada i el monestir. Per la seva càrrega simbòlica, i també pel seu impacte sobre l'economia pagesa, l'alberga fou un dels drets més emblemàtics de la senyoria ${ }^{27}$.

Trobant-se la precària del mas Saltells i la querimònia separades per gairebé trenta anys, la identificació dels personatges d'un i altre text resta força insegura. Tot i així, és possible que la femina de l'abat, Adelaida de Saltells, objecte de la donació-establiment de 1132 fos la domina de manso Saltells de la querimònia. Ambdues denominacions, femina ${ }^{28}$ i domina ${ }^{29}$, aplicades a la tinent del mas reforcen la idea que ens trobem davant d'un mas especial, més proper d'una petita senyoria territorial que d'una explotació agrària.

En aquest cas, resultaria temptador d'identificar Berenguer de Saltells, batlle del Montcada, amb el Berenguer Arnau de la precària de 1132, l'espós d'Adelaida, que l'any 1150 havia edificat un molí en terres dels Montcada i que, segons la querimònia, tenia el mas Saltells per Sant $\mathrm{Cugat}^{30}$. No es pot descartar que Berenguer perseguís de foragitar del mas la seva pròpia muller (ho seria encara?) per a vindicar-ne la propietat. Si Berenguer Arnau era el batlle dels Montcada, que assumí el toponímic Saltells després d'entrar en el mas, les prevencions de la precària de 1132, la prohibició d'hostatjar els senyors del castell i l'exigència de solidesa respecte a l'abat, tindrien ple sentit.

${ }^{27} \mathrm{~L}$ 'exercici arbitrari del dret d'alberga sobre dominis eclesiàstics o comtals fou un dels abusos més freqüentment denunciats a les querimònies (GARÍ, Las "querimoniae", p. 22) i més citats en els actes de definició (SALRACH, "Multa placita et contenciones"). També a Castella les exaccions del conducho i del yantar són les formes més comunes d'extorsió nobiliària (Salustiano MORETA, Malhechores-feudales. Violencia, antagonismos y alianzas de clases en Castilla, siglos XIII-XIV, Madrid, Cátedra, 1978, pp. 62-63).

${ }^{28}$ Segons Gaspar Feliu, Activitats econòmiques, "Història de Barcelona", vol. 2. ("La formació de la Barcelona medieval"), Barcelona, Ajuntament de Barcelona - Fundació Enciclopèdia Catalana, 1992, pp. 217, el mot femina seria un tractament específic reservat a dones de condició social elevada.

${ }^{29} \mathrm{El}$ títol de domna, exclusiu dels grans llinatges feudals, comença a ésser utilitzat per les dones de llinatges de castlans a partir dels anys centrals del segle XII. GARÍ a Las "querimoniae" cita els casos d'Amafad (p. 28) i Guília de Banyeres (p. 35).

${ }^{30}$ L'any 1150 Berenguer de Saltells posseia a la riba del riu Major, sota la muntanya de Cerdanyola que Ramon Guillem de Montcada concedí per a edificar el monestir de Valldaura, un molí i un mas annexe. Quatre anys més tard Guillem Ramon de Montcada concedí aquest molí al monestir. Cf. Antoni CARRERAS I CASANOVAS, El monestir de Santes Creus. 1150-1200, Valls, Institut d'Estudis Vallencs, 1992, I, pp. 16-18. 
Prop del mas Saltells, Guillem de Montcada i Berenguer de Saltells davastaren també les dominicatures de Bellveí i de Ripollet ${ }^{31}$, i assaltaren els masos de Pere de Sales i Pere Guiribert, dels quals hom especifica la condició d'homes "diumengers" de Sant Cugat (dominicus homo), i un mas situat al bosc, també dominicum del monestir.

L'objectiu principal de Guillem de Montcada i de la seva mainada és aconseguir l'abandó del mas Saltells. L'escomesa s'inicia amb el tancament del camí de la font que aportava l'aigua al mas ${ }^{32}$, element indispensable per a la vida i l'activitat agrària, i el robatori de 26 xais i 22 quarteres de blat. Continua amb la intimidació dels habitants del mas mitjançant l'amenaça o l'exercici de la violència física. Guillem de Montcada amenaça d'agafar la senyora i de cremar-la si no abandona el mas, i a tots els homes i dones que hi troba de tallar-los els peus i les orelles i d'arrencar-los els ulls, les formes clàssiques del terrorisme nobiliari de l'època ${ }^{33}$. Com a conseqüència de tot plegat, el mas és abandonat i destruït perquè, en expressió de la mateixa querimònia, "ningú gosa estar-s'hi".

Aparentment, els Montcada han reeixit als primers intents. Els següents episodis del relat revelen, però, la resistència de la senyora del mas a marxar. Aquest fet sembla motivar la intervenció del batlle del Montcada, Berenguer de Saltells, que espasa en mà amenaça de matar la senyora del mas, la qual, aterrida, fuig i abandona el mas. Diu el relat que Berenguer, que fins

\footnotetext{
${ }^{31}$ Aquestes terres que els abats de Sant Cugat es reservaren per a la seva explotació directa estaven situades a les planes fèrtils de la confluència dels rius Ripoll i Besòs, molt a prop del castell de Montcada. Dividides en parellades i destinades principalment al conreu dels cereals, foren confiades a personatges estretament vinculats a la institució monàstica per a explotar-les en règim de mitgeria. L'any 1169 l'abat Ramon cedí vitalíciament al prevere Joan dues parellades de la dominicatura de Ripollet, situades una al damunt i l'altra sota l'església, per a conrear a mitges (ACA, Monacals, Sant Cugat del Vallès, perg. 561). La dominicatura de Bellveí estava situada dins del terme de Reixac. L'any 1258 l'abat Pere lloà i confirmà a Elisenda, filla de Guillem de Bellveí, el mas Bellveí. La lloació comprenia tres parellades, una situada al davant la porta del mas, una altra al damunt del camí que anava de Bellveí a Barcelona i la tercera al damunt la sagrera de Bellveí, i dues altres feixes de terra, que en endavant Elisenda hauria de conrear-les en règim de mitgeria. La vigència d'aquest sistema d'explotació, característic de les terres tingudes en règim d'explotació directa, torna probable la hipòtesi que aquestes parellades, adscrites com a tinences dels masos, procedissin de la parcel.lació de l'antiga dominicatura (1258: ACA, Monacals, Sant Cugat del Vallès, perg. 1310).

${ }^{32}$ Aquesta acció evoca a petita escala el tallament del subministrament d'aigua a Barcelona que perpetrà el senescal contra el comte com a represàlia per haver promogut l'abandó de la seva esposa Beatriu al seu vassall Guillem III de Sant Martí (SHIDELER, The Montcadas, p. 91).

${ }^{33}$ Accions $\mathrm{i}$ amenaces similars figuren a la querimònia coetània que Guillem Ramon II de Castellvell dirigeix contra el seu castlà Berenguer del Castellvell de Rosanes (GARí, Las "querimoniae", pp. 24-25).
} 
aleshores havia tingut l'honor per l'abat de Sant $\mathrm{Cugat}^{34}$, ara el vindica com a alou propi i del seu senyor. La insistència de la querimònia en la fugida de la senyora per a demostrar que fou forçada, i no pas voluntària, posa de relleu la profunda significació jurídica de la residència permanent del tinent en el mas $^{35}$. Per al batlle, armat, la senyora del mas és essencialment un entrebanc jurídic, no pas físic, per a poder-ne vindicar la propietat; aconseguir la seva fugida i l'abandó total del mas serà, doncs, un objectiu prioritari.

L'exercici arbitrari de la violència implica una transgressió de l'ordre establert, de la pau territorial i eclesiàstica. Guillem de Montcada és representat com el típic iuvenis de la classe nobiliària, que no s'atura davant de res ni de ningú, desafiant tota autoritat temporal i espiritual. Pocs textos il-lustren tan bé aquesta actitud tan profundament feudal com l'episodi de la trobada dels monjos amb el Montcada i el posterior assalt del mas Saltells el dia dels Innocents. Aquest dia Guillem de Montcada passava per davant del monestir i els monjos sortiren al seu encontre. L'actitud humil dels monjos que suplicaren al Montcada que per Déu, per Sant Cugat ${ }^{36}$ i pel comte aturés la persecució, constrasta vivament amb l'arrogància del noble que, menyspreant les paraules dels monjos, els contestà grollerament i sense pietat (male atque durissime) "que ni pel comte ni pel bisbe, mentre visqués no deixaria de perseguir-los tant com pogués" ${ }^{37}$. El vespre d'aquell mateix dia -segueix la querimònia- Guillem de Montcada anà al mas Saltells i hi envià els seus homes armats, cavallers i escuders (armigeris), amb els cavalls, i altres homes pagesos, els quals regiraren tota la roba de la casa, tombaren dotze botes de vi, destruiren els colomars, beberen, abocaren i s'emportaren el vi i prengueren el blat que els monjos havien comprat.

${ }^{34}$ És possible que Berenguer de Saltells, que era batlle de Guillem de Montcada, tingués el mas Saltells en feu pel monestir, el que explicaria millor una animadversió cap als tinents del mas.

${ }^{35}$ En aquesta època l'estatge (staticam) o residència permanent del tinent en el mas és ja una obligació generalitzada en les concessions precàries.

${ }^{36}$ Fixem-nos que, tot i la resposta del Montcada, el nom del bisbe no és invocat pels monjos. Des de l'episodi de Tomeres (vegeu n. 3) Sant Cugat serà un monestir exempt de la jurisdicció episcopal fins que el 1251, després d'un llarg plet iniciat l'any 1211, sigui definitivament subjectat a la mitra pel papa Innocenci IV (Josep BAUCELLS I REIG, Qüestions sobre l'exempció episcopal d'alguns priorats de Barcelona-diòcesi (s. XIV) i del monestir de Sant Cugat del Vallès (s. XI al XIV), "I Col.loqui d'Història del Monaquisme Català", I, Santes Creus, 1967, 32-46).

${ }^{37}$ Un actitud similar sembla caracteritzar les accions de Berenguer de Bleda i del seu castlà. Els homes de Fontrubí diran a Alfons I que el castlà i els seus armigers i bagasés actuen talment com si no tinguessin temor del rei ni de Déu: "faciunt sicut nobis et nos neque rex neque Deus non est illis valent" (ACA, Cancelleria, Extrainventari, perg. 3288). 
A mesura que avancem en el relat la violència lúdica, pròpia de les formes de comportament dels iuvenes de la classe nobiliària ${ }^{38}$, cedeix davant del pillatge mogut per motivacions purament materials ${ }^{39}$. L'extorsió del Montcada adopta tres formes bàsiques:

a) El robatori, principalment de blat, farratge i bestiar, però també d'atuells i objectes de la llar.

Guillem de Montcada i els seus homes prengueren, inicialment, del mas Saltells 26 xais i 22 quarteres de forment que la senyora havia encarregat a Ramon de Cerdanyola. En un altra ocasió, assaltaren el mas de Pere de Sales, home dominicus de Sant Cugat, i s'endugueren molts béns (multum avere), que després es negaren a retornar a l'abat. A la dominicatura de Ripollet es ficaren en els horts i els vergers, colliren els fruits i segaren i s'emportaren el farratge. Finalment, el dia de Sant Esteve, entraren en el mas Saltells, prengueren 20 quarteres d'ordi, trecaren els atuells, i també se n'endugueren alguns, trencaren les portes i les finestres i s'emportaren els forrellats.

Del tot aquest botí sobresurt, per la seva magnitud, el blat. Guillem de Montcada i els seus homes robaren, en total, més de 102 quarteres $^{40}$, entre forment (42 q.), ordi (40 q.) i espelta (20 q.) -si comptem les 60 quarteres obtingudes del rescat d'un home-, potser per a satisfer les necessitats de la mainada, potser també per a enriquir-se amb l'àgio en un context de crisi frumentària ${ }^{41}$.

b) El segrest d'homes per tal de fer-los redimir per importants sumes de numerari o per quantitats de cereals ${ }^{42}$.

${ }^{38}$ Sobre el concepte de "violència lúdica" vegeu Georges DUBY, Les "jeunes" dans la société aristocratique dans la France du Nord-Ouest au XII siècle, "Annales E.S.C.", 19 (set.-oct. 1964), pp. 216-217.

${ }^{39}$ Les querimònies mostren, millor que cap altra font històrica, fins a quin punt la pràctica sistemàtica del pillatge com a font d'enriquiment immediat s'integra dins les formes de conducta dels feudals. Cf. Garí, Las "querimoniae"..., p. 24.

${ }^{40}$ Una quantitat important, equivalent aproximadament a uns 5900 litres, si li apliquen l'equivalència de la quartera vella de Barcelona, en curs a l'època.

${ }^{41}$ La hipòtesi d'una crisi agrària els anys 1160-1161 és corroborada per una brusca caiguda de la producció de contractes agraris.

${ }^{42} \mathrm{La}$ pràctica del segrest d'homes per tal de fer-los redimir fou una pràctica generalitzada a la segona meitat del segle XII - gairebé no hi ha querimònia on no aparegui una denúncia d'aquest tipus-, (Cf. Josep M ${ }^{\text {a }}$ SALRACH, Agressions senyorials $i$ resistències pageses en el procés de feudalització (s. IX-XII), "Revoltes populars contra el poder de l'Estat. Reus, 18-20 octubre 1990", Barcelona, Generalitat de Catalunya, 1992, p. 24), el que sens dubte tingué a 
Guillem de Montcada agafà un home de Sant Cugat anomenat Bernat de Pedrecs i el ficà en una gruta (foveam). L'abat, per mitjà dels seus monjos ${ }^{43}$, el reclamà en nom del comte, però Guillem de Montcada refusà escoltar-lo i el féu redimir per 60 quarteres de blat, entre forment, ordi i espelta.

Berenguer de Saltells raptà l'esclau sarraí del mas de Pere Guiribert, home de Sant Cugat, i no el tornà fins que el mateix Pere Guiribert no li hagué satisfet el rescat. En una altra ocasió forçà un mas dominicum del monestir situat en el bosc i s'endugué un home encadenat - segurament un altre esclau-, el qual ficà dins d'una gruta. L'abat i els monjos el reclamaren a Guillem de Montcada i al seu batlle, però aquests es negaren a tornar-lo i obligaren l'home a redimir-se. El dissabte abans de Nadal Bernat de Castlarí es dirigí, per ordre de Berenguer de Saltells, al mas Saltells on trobà un noi jove que llaurava amb bous i altres dos que cavaven la vinya. Els agafà i els ficà a la presó del castell (tavegam). Aquesta acció fou presenciada per la senyora del mas que, aterrida, fugí al monestir.

Dels sis homes segrestats, només un, Bernat de Pedrecs, significativament l'únic capturat pel Montcada, és dependent directament de Sant Cugat; la seva redempció per una quantitat important de cereals, l'única consignada a la querimònia, és exigida a l'abat $\mathrm{i}$ als seus monjos. Un cop més, la invocació de l'autoritat comtal resulta inútil. Entre els segrestats pel batlle Berenguer de Saltells, en canvi, figuren dos esclaus, un d'ells sarrai ${ }^{44}$, i tres nois, que els pagesos devien emprar com a mà d'obra subalterna en les feines de la terra i que, a més, garantien l'ocupació dels masos; la seva redempció és exigida als seus amos, homes de Sant Cugat, i possiblement per això la quantitat no és anotada a la querimònia.

c) Les exaccions arbitràries de béns i numerari sobre els homes del monestir. Guillem de Montcada exigí la qüèstia dues o tres vegades l'any

veure amb la institucionalització del Ius maletractandi.

${ }^{43}$ Ramon de Sentmenat evita, com ho farà el dia dels Innocents, haver d'entendre's directament amb el Montcada. Hi havia una relació personal d'enemistat, o d'amistat?

${ }^{44}$ Aquests esclaus es trobaven encadenats a l'interior dels masos. Segons Aurell durant les conquestes de la Catalunya Nova, nombrosos sarraïns foren capturats, reduïts a esclavitud deportats a la rereguarda. Cf. Martin AURELL, Esclavage et croisade dans la Vie et miracles de l'evêque Oleguer ( $† 1137)$ de Barcelone, "Les sociétés méridionales à l'âge féodal (Espagne, Italie et sud de la France, Xe-XIIIe s.). Hommage à Pierre Bonnassie", Tolosa, Université de Toulouse-Le Mirail, 1999, p. 90. 
sobre els homes dependents de Sant Cugat a la dominicatura de Bellveí. L'arbitrarietat és doble. Guillem de Montcada imposà el cobrament de sumes de numerari als homes de Sant Cugat "que no havien de fer res per ell" (qui per illum nichil facere habent) $\mathrm{i}$, a més, ho féu dues o tres vegades l'any, és a dir, més enllà del que devia considerar-se consuetudinari. El clàssic conflicte entre la senyoria castral, que preten exercir determinats drets sobre tots els habitants del territori, i la senyoria alodial ja es troba aquí plantejat.

\section{GUILLEM III DE SANT MARTí: LES DOMINICATURES DE CASTELLDEFELS I TORRES BECES}

La segona querimònia denuncia els actes de pillatge perpetrats per Guillem III de Sant Martí, veguer d'Eramprunyà i senyor d'Olèrdola i de Sant Martí Sarroca, a les dominicatures del monestir de Castelldefels (Baix Llobregat) i Torres Beces (Alt Penedès) ${ }^{45}$.

A Castelldefels Guillem de Sant Martí robà el peix ${ }^{46}$ que el batlle de Sant Cugat volia enviar a l'abat per Nadal. Tot seguit recorregué amb els seus

\footnotetext{
${ }^{45}$ Aquesta querimònia ha de posar-se en relació amb una altra que relata accions similars perpetrades pel mateix Guillem de Sant Martí i els seus homes contra els homes del comte de les localitats veînes de Gavà, Sant Climent i Viladecans, dins del terme del castell d'Eramprunyà. La querimònia denuncia que Guillem de Sant Martí assaltà les sagreres de Gavà, Sant Climent i Viladecans i prengué els ases per la força, els quals utilitzà per a fer els seus tragins; que, acompanyat dels seus armigeri, tallà les messes dels pagesos del comte; que robà a Bernat Miró de Camp 10 quarteres d'ordi "perquè defensava les seves vinyes dels seus homes"; que prengué al comte la parellada de Colomer, l'hort de Fontanles i la farga de Sant Climent; que robà diverses quantitats de gra i de diner als pagesos; que segrestà un home que tenia Arnau Bonús; que els seus batlles flagel-len els homes del comte i foraden les botes de vi de dos homes; que prengué un porc a un home; que ell i els seus agafaren el batlle del comte (ha de tractar-se de Tició o Tidó) i li tiraren una llança; que desemparà l'honor que Tició havia emparat per manament del comte; que prengué l'honor d'A. de Pla i de la seva mare; que fuetejà els homes del comte que no volien anar a la talla (del bosc); que el seu batlle assaltà la casa de Bertran de Sant Climent i tragué un porc, que prengué albergues a les sagreres del comte i multa alias forsfacturas quod non debebat facere; que prengueren els xais i les cabres als forasters que anaven i venien a la sagrera del comte i els hi feren redimir per ordi i diners (ACA, Cancelleria, Extrainventari, perg. 3451).

${ }^{46}$ La dominicatura de Castelldefels, que s'estenia des de la Roca de Gavà fins al Garraf per la línia de la costa, constituîa, amb els seus estanys i aiguamolls, una important reserva de pesca. La infeudació que l'any 1178 féu l'abat Guillem a Tició i Alamanda i als seus fills Guillem Ramon de la casa i la dominicatura cum mansis, terris et vineis et montibus et boschis, cum pascuis, lignis, aquis et stagnis et piscatis et cum venacionibus et trobes fa referència, entre les obligacions dels receptors, al pagament anual al monestir de 100 peses de blat i 5 peixos (scathos) per Sant Cugat (ACA, CSC, f. 280v, doc. 869 [còpia del s. XIII], Monacals, Sant Cugat del Vallès, perg. 595 [trasllat del 9 de maig de 1223], RIUS, III, pp. 270-271, núm. 1117).
} 
batlles els masos de la dominicatura, els assaltà i prengué set pernes de porc. En un altra ocasió, envià els seus batlles a la dominicatura de Torres Beces ${ }^{47}$, els quals per manament seu forçaren tres masos i s'emportaren les dalles i les aixades ${ }^{48}$.

Tot i que molt més breu, aquesta querimònia presenta una unitat d'estil amb l'anterior. La referència a la diada de Nadal permet, d'altra banda, suposar que els dos episodis relatats, pròxims a aquesta data, foren coetanis dels fets relatats a la querimònia anterior, els quatre episodis datats de la qual tingueren lloc el mes de desembre i, concretament, pels volts de Nadal, i que com aquests han de ser propers a la redacció del document.

Finalment cal destacar alguns paral-lelismes entre els clamores contra Guillem de Montcada i la querimònia de Guillem de Sant Martí: la situació dels dominis monàstics afectats dins del territori controlat militarment pels nobles agressors ${ }^{49}$; l'origen comtal d'alguns d'aquests dominis, circumstància que fou recollida pels redactors de la querimònia ${ }^{50}$, sens dubte, amb la intenció que Ramon Berenguer IV considerés les agressions com a quelcom que el concernia directament; l'estreta vinculació personal existent entre el

${ }^{47}$ Udina, Cartulario, vol. IV (Madrid, Ministerio de Cultura, 1981), p. 61, identifica el lloc de Torres Beces amb un mas situat al terme de Sant Sebastià dels Gorgs, a l'actual municipi d'Avinyonet $\mathrm{i}$ antic terme del castell d'Olèrdola (Alt Penedès). L'origen de la dominicatura cal situar-lo en l'establiment que l'any 1014 féu l'abat Guitard a Ellemar i a la seva muller Emma de dues parellades amb un prat situat a Torres Beces, per a edificar una torre, amb els farraginals que hi havia al voltant de la torre, a canvi de la prestació anual de tres lliures de cera (ACA, CSC, f. 142, doc. 459, RIUS, II, pp. 105-106, núm. 458). L'any 1111 l'abat Roland establí l'alou que fou de Nèvia i la batllia de Torres Beces a Arnau Berenguer i als seus descendents (ACA, CSC, f. 142, doc. 460, RIUS, III, pp. 15-16, núm. 814). L'any 1176 l'abat Guillem encomanà la batllia de Torres Beces a Bertran de Soler (ACA, CSC, f. 141v, doc. 458; RIUS, III, pp. 264265, núm. 1110).

${ }^{48} \mathrm{El}$ robatori d'eines agrícoles, especialment de ferro, fou, possiblement pel seu cost elevat, una de les formes més comunes d'extorsió fins al punt que el concili de Lleida de 1155 l'assamblea de Pau de Fondarella del 1173 establiren la seva protecció (GoNZALVO, La Pau i la Treva, pp. 29-49; Les constitucions de Pau i Treva, p. 58 i 79).

${ }^{49} \mathrm{El}$ mas Saltells i de les dominicatures de Ripollet i Bellveí es trobaven dins dels termes dels castells de Sant Marçal i de Montcada. La dominicatura de Castelldefels formava part del terme del castell comtal d'Eramprunyà i la dominicatura de Torres Beces estava situada dins del terme del castell d'Olèrdola. Les querimònies monàstiques concerneixen els alous, dominicatures i masos, enclavats dins dels territoris castrals controlats militarment pels nobles; la violència contra les pagesos devia ésser, però, un fenòmen general en aquests territoris (SALRACH, Agressions senyorials, p. 22; BISSON, Tormented Voices, p. 106).

${ }^{50} \mathrm{El}$ domini de Castelldefels fou donat a Sant Cugat pels comtes Borrell i Letgarda entre el 981 i 988 (ACA, CSC, f. 268, doc. 831, RIUS, II, pp. 80-81, núm. 436 [1011]). Vegeu n. 92 de l'apèndix. 
nobles agressors i el comte ${ }^{51}$; i el paper actiu dels batlles locals, que, armats, protagonitzaren les accions devastadores dels masos ${ }^{52}$.

\section{LA PENYORA DE GALLECS \\ I EL PLET SOBRE EL CASTELL DE SANT VICENÇ DE CALDERS}

Les dues querimònies que segueixen presenten sengles conflictes entre el monestir i alguns nobles als quals la comunitat acusa d'haver usurpat determinats dominis, drets i rendes. Abandonem, doncs, el terreny de la violència i del bandidatge senyorial contra la pagesia $i$, amb ell, l'estil narratiu, per a abordar dos contenciosos de caràcter jurídic. Ambdues querimònies suposen, doncs, un viratge respecte dels fets relatats a les dues anteriors, els quals, esdevinguts en un lapse relativament curt de temps $\mathrm{i}$ recents en la memòria dels monjos, semblen haver estat el veritable mòbil de la redacció del document. La inclusió d'ambdues notícies sobre dos plets irresolts dins d'un únic document adreçat al tribunal comtal obeí essencialment a motius tàctics.

A la tercera querimònia l'abat i els monjos de Sant Cugat acusen Ponç Guerau d'Olorda i Arnau de Ribes de retenir indegudament l'honor de Gallecs que tenien en penyora. Umbert de Cervelló havia empenyorat aquest honor per 150 sous al pare de Ponç, Guerau Gombau. Posteriorment, l'havia deixat a Sant Cugat en el seu testament amb la condició que l'abat i els monjos del monestir el redimissin a Guerau Gombau o als seus fills. Diu la querimònia que tot i que l'abat i els monjos de Sant Cugat expressaren diverses vegades

\footnotetext{
${ }^{51}$ Guillem III de Sant Martí, fill de Jordà I i d'Anglesa, succeí Guillem Ramon com a vicari del castell comtal d'Eramprunyà. L'any 1135 fou promogut per Ramon Berenguer IV a esposar Beatriu de Montcada i heretar, d'aquesta manera, la senyoria de Montcada. Els projectes polítics del comte de Barcelona toparen amb l'existència d'uns pactes matrimonials anteriors entre el senescal Guillem Ramon i Berenguer Ramon de Montcada, pare de Beatriu. El conflicte entre el comte i el senescal es resolgué l'any següent amb un acord que preveia el divorci de Beatriu i Guillem Ramon, una divisió de propietats per la qual l'herència dels Montcada passava als fills de Guillem Ramon i de Beatriu, i una redefinició de les relacions entre el senescal i el comte segons la qual Guillem Ramon passava a ésser feudatari del comte pels castells del seu patrimon (SHIDELER, The Montcadas, pp. 91-92). Guillem de Sant Martí consta per primera vegada com a vicari comtal del castell d'Eramprunyà el 1143 quan n'encomanà la castlania a Pere de Santa Oliva, fill de l'anterior vicari, Guillem Ramon (CR, XX, p. 363).

${ }^{52} \mathrm{~A}$ la mateixa època Tidó, batlle del comte, protagonitza en els mateixos dominis comtals de Castelldefels, Viladecans i Gavà "malifetes" diverses i actes de pillatge recollits en una querimònia adreçada a Ramon Berenguer IV (ACA, Cancelleria, Extrainventari, perg. 4732).
} 
la voluntat de redimir-lo a Ponç Guerau i Arnau de Ribes, aquests no volgueren recuperar el diner i alliberar l'honor.

La quarta querimònia presenta un plet entre el monestir de Sant Cugat i Arnau de Benages i Berenguer d'Ollers pel domini del castell de Sant Vicenç de Calders (Baix Penedès) ${ }^{53}$ i amb Bernat de Castellnou pel delme de Rafeguera (Alt Penedès) ${ }^{54}$.

Explica la querimònia que ja feia temps l'abat Ramon i els monjos havien elevat diverses vegades al comte de Barcelona la seva queixa enèrgica contra aquests nobles. A Arnau de Benages i Berenguer d'Ollers els acusaven d'haver-se apropiat indegudament del castell de Sant Vicenç de Calders i a Bernat de Castellnou d'haver usurpat el delme de Rafeguera. El comte els havia convocat a la seva cúria per tal que ho redrecessin al monestir. Arnau de Benages i Bernat de Castellnou comparegueren davant del tribunal comtal i pledejaren amb l'abat i els monjos de Sant Cugat. El comte, després d'haver escoltat les parts i d'haver llegit un document presentat per la comunitat, sentencià que tot aquest honor (el castell de Sant Vicenç i el delme de Rafeguera) pertanyia al monestir. Tot seguit, l'emparà i el lliurà a l'abat i als monjos, i manà al seu batlle Berenguer d'Avinyó ${ }^{55}$ que procedís de la mateixa manera. Bernat de Castellnou, però, desemparà el delme de Rafeguera i encara el retenia sense dret.

Berenguer d'Ollers no havia volgut comparèixer a judici i, un cop hagué conegut la sentència, digué estar en possessió d'un document que provava les seves pretensions i les dels altres nobles sobre l'honor en qüestió $^{56}$. L'abat i els monjos acudiren altre cop al comte i li explicaren el que Berenguer d'Ollers deia. El comte ordenà que ambdós documents, el de Sant

\footnotetext{
${ }^{53} \mathrm{El}$ castell de Sant Vicenç de Calders, situat dins l'actual terme del Vendrell i avui desaparegut, fou un domini de Sant Cugat del Vallès des dels inicis de la repoblació del territori al segle $\mathrm{X}$, tot $\mathrm{i}$ que fins al segle XI no apareix en la documentació com a tal, diferenciat del veí castell de Calders, amb el qual formava inicialment un mateix territori (CR, XIX, p. 43).

${ }^{54}$ Es tracta del delme dels molins de la dominicatura de Rafeguera, situada dins del terme de Santa Margarida i els Monjos (Alt Penedès). Vegeu mapa 1.

${ }^{55}$ Documentat l'any 1156 quan Ramon Berenguer IV li encomanà el puig d'Avinyó (Thomas N. BISSON, Fiscal accounts of Catalonia under the early count-kings (1151-1213), Berkeley-Los Ángeles-Londres, University of California Press, 1984, I, p. 206).

${ }^{56} \mathrm{La}$ reinvidació de Berenguer ja no inclou el delme dels molins de Rafeguera que havia estat definit al monestir pel seu pare, Oller, el 30 d'abril del 1161. En el document, copiat al Cartulari, Oller reconegué que tenia els molins per Sant Cugat i que mai no va donar el delme (ACA, CSC, f. 120v, doc. 400 , Rius, III, p. 207, núm. 1038).
} 
Cugat i el de Berenguer d'Ollers, fossin lliurats en potestat del jutge Borrell de Girona ${ }^{57}$ perquè els examinés i resolgués el conflicte.

El judici de Borrell al qual fa referència la querimònia fou celebrat a l'església de Sant Genís de Martorell el 2 d'octubre del 1160 i el seu contingut ens és conegut gràcies a la còpia del Cartulari ${ }^{58}$. En el judici Arnau de Benages i Berenguer d'Ollers afirmaren que tenien el castell de Sant Vicenç per l'abat i els monjos de Sant Cugat i, per a provar-ho, presentaren una escriptura atorgada per l'abat Berenguer ${ }^{59}$ a Ramon Màger i a Pere Bernat i als seus successors. Els monjos, per la seva banda, negaren qualsevol dret d'aquests nobles sobre el castell i oposaren una altra escriptura atorgada per l'abat Andreu al mateix Ramon Màger ${ }^{60}$. El jutge Borrell, a l'hora d'inclinarse per una o altra escriptura, que segons la notícia del judici presentaven contradiccions ${ }^{61}$, optà per criteris tècnics: declarà vàlida la carta atorgada per l'abat Andreu en aquells punts que diferia del document presentat pels nobles perquè estava validada amb els signes dels monjos i sense validesa aquesta segona escriptura perquè únicament era roborada per la signatura de l'abat ${ }^{62}$.

Berenguer d'Ollers - segueix la querimònia-, un cop coneguda la sentència desfavorable a les seves pretensions, aconsellat per Guillem de

${ }^{57}$ Borrell, un home de confiança de Ramon Berenguer IV, actua en un altre judici coetani (ACA, CSC, f. 170, doc. 546, RIUS, III, pp. 205-206, doc. 1036).

${ }^{58} \mathrm{ACA}, \mathrm{CSC}$, f. 104, doc. 350, RiUs, III, p. 205, núm. 1035

${ }^{59} \mathrm{Ha}$ de tractar-se de Berenguer Folc, bisbe de Barcelona i abat de Sant Cugat. L'escriptura, que òbviament no s'ha conservat a l'arxiu monàstic, ha de datar-se entre el 1091 i el 1104.

${ }^{60}$ Aquesta escriptura, copiada al Cartulari, constitueix la primera infeudació documentada del castell de Sant Vicenç de Calders. Es tracta de la convinença que l'abat Andreu de Sant Cugat establí el 13 de gener de l'any 1082 amb Ramon Màger, la seva muller Adales, els seus fills i filles i el seu germà Guerau. L'abat els hi donà el castell de Sant Vicenç amb el pacte que dins dels deu anys següents reconstruïssin la torre, fessin una casa prop de la torre i repoblessin les terres en la mesura que poguessin. Els hi donà la meitat del terme del castell en alou i l'altra meitat en feu mentre visquessin, i retingué en domini la quarta part d'una i altra meitat i de tots els delmes (ACA, Monacals, Sant Cugat del Vallès, perg. 340; CSC, f. 102, doc. 348 [còpia del s. XIII], RIUS, II, pp. 368-370, núm. 707).

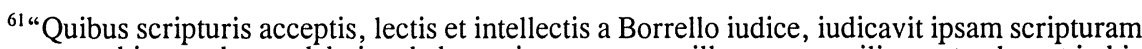
quam monachi ostenderent debuisse habere vigorem contra illam quam milites ostenderunt in his quem scriptura militum erant contra scripturam sancti Cucuphatis".

62، Propter hoc quia scriptura illa confirmata ab Andrea abbate erat corroborata signis et confirmacionibus quamplurium monachorum eiusdem conventus, aliam vero scripturam militum iudicavit invalidam in his que erant contraria priori scripture sancti Cucuphatis, quia solus abbas ibi confirmatus fuerat auctoritate canonum qui dicunt sentenciam prelatorum non debere valere sine conveniencia subiectorum suorum". 
Papiol $^{63}$, la recusà i refusà d'acatar-ne cap altra, ja procedís de l'arquebisbe, d'altres homes (aliorum hominum) ${ }^{64}$ o de la cúria del comte. Tot seguit es dirigí cap al castell de Sant Vicenç, el desemparà, matà les ovelles de Sant Cugat, robà els anyells i els formatges, destrossà les arades, s'emportà els agrers i amenaçà de ferir i matar tots els monjos i homes que hi trobava. La reacció d'Ollers il·lustra la decepció d'un noble davant la nova justícia tecnificada basada en la primacia del dret escrit que, paral-lelament al renaixement de la justícia comtal, emergeix amb força a partir de mitjan segle $\mathrm{XII}{ }^{65}$.

\section{EL RETORN DE GUILLEM DE MONTCADA: LES VEXACIONS A LA COMUNITAT MONÀSTICA}

La cinquena i darrera part del document és una nova querimònia de l'abat i els monjos de Sant Cugat contra Guillem de Montcada: l'objecte de la queixa són, aquesta vegada, les vexacions sofertes directament per la comunitat, dins del recinte monàstic. Aquesta darrera querimònia reprèn i complementa el relat inicial centrat en les accions del noble contra els homes i les possessions del monestir. El creuament de la informació aportada per una i altra querimònia permet reconstruir una única seqüència d'esdeveniments que haurien tingut lloc en un mateix any, entre Pasqua i els Innocents, i respondrien a una mateixa campanya dirigida pel fill del Senescal contra els interessos del monestir. L'estil d'aquesta darrera querimònia difereix, però, radicalment de les dues primeres, el que justifica la seva desvinculació i la seva col·locació deliberada al final del document.

\footnotetext{
${ }^{63}$ Guillem de Papiol, un dels homes de confiança de Berenguer d'Ollers, actuarà com a lloador i amicable componedor en el judici entre aquest i Sant Cugat del 13 de setembre de 1163 (ACA, CSC, f. 103, doc. 351, RIUS, III, pp. 215-216, núm. 1050).

${ }^{64} \mathrm{En}$ el període que va de 1060 a 1196 la forma més comuna de dirimir els conflictes foren les assamblees d'homes bons o prohoms, constituïdes generalment per magnats, tot i que també trobem tribunals presidits per un o diversos jutges. Cf. SALRACH, "Multa placita et contenciones".

${ }^{65}$ Josep Ma SALRACH, Prácticas judiciales, transformación social y acción política en Cataluña (siglos IX-XIII), "Hispania”, LVII/3, núm. 197 (1997), pp. 1040-1041.
} 
L'abat i els monjos de Sant Cugat prenen la paraula i es dirigeixen al comte en primera persona ${ }^{66}$ per a explicar-li allò que més els ha dolgut de tot plegat (quod magnum nobis grave est), les vexacions de les quals han estat víctimes, i finalment allò que creuen més greu li ha de saber (quod domino comiti Barchinonensi peius debet esse), les pretensions de Guillem de Montcada de tenir la guarda i batllia del monestir. Aquest canvi d'estil i el dramatisme de la declaració just a la part final del document tenen un objectiu evident: commoure el comte i impel-lir-lo a que faci justícia.

Els monjos denuncien que Guillem de Montcada, acompanyat dels seus homes armats i d'altres fidels seus, ha exercit arbitràriament (per malum usaticum) un dret de cena i alberga en el monestir. Guillem de Montcada ha trencat la Pau i Treva de Déu: ha violat diverses vegades la intimitat del recinte monàstic ${ }^{67}$ en dies assenyalats del calendari litúrgic ${ }^{68}$. Per a convèncer al comte de la veracitat de l'acusació (ut vere credatis), li presenten una relació dels dies que al llarg de l'any, entre Pasqua i Nadal, Guillem de Montcada ha anat al monestir i s'hi ha estatjat amb el nombre aproximat d'homes i de bésties que l'han acompanyat cada vegada. Aquests detalls semblen indicar l'existència d'una memòria escrita, d'un diari previ en el qual $s^{\prime}$ haurien basat els monjos per a la redacció de la querimònia ${ }^{69}$. La informació empírica és emprada pels redactors com un recurs per a contrarestar el

\footnotetext{
${ }^{66}$ Lliscaments com aquest, cap a la primera persona a la part final del document, es troben també a les querimònies comtals, com la que els homes de Font-rubí adreçaren al rei Alfons contra Berenguer de Bleda. Cf. BISSON, The crisis, p. 164; Tormented voices, pp. 15-17.

${ }^{67}$ Les assemblees de Pau i Treva del 1064 i 1131 i el concili provincial de Lleida de 1155 establiren la protecció dels monjos i clergues desarmats i de monestirs i canongies. Gener Gonzalvo i Bou, La Pau i la Treva a Catalunya. Origen de les Corts Catalanes, Barcelona, Institut Municipal d'Història - Ed. La Magrana, 1986., pp. 29-49; Gener GoNZALVO I Bou (ed.), Les constitucions de Pau i Treva de Catalunya (segles XI-XIII), Barcelona, Generalitat de Catalunya - Departament de Justícia, 1994.

${ }^{68}$ L'assemblea celebrada a Toluges vers $1064-1066$ posà sota la Treva de Déu diversos períodes i dies festius del calendari litúrgic, entre ells, les tres festivitats de la Mare de Déu amb les seves vigílies, les dotze festivitats dels apòstols amb les seves vigílies i el període que va del primer dia d'Advent fins a les octaves de l'Epifania (GoNZALVO (ed.), Les constitucions, pp. 3334).

${ }^{69} \mathrm{De}$ la relació d'episodis datats d'una i altra querimònia (vegeu taula I) es desprèn que els monjos haurien comencat per anotar els dies que Guillem de Montcada i els seus homes s'estatjaren al monestir i posteriorment, el mes de desembre, haurien incorporat al suposat diari les notícies dels darrers assalts del mas Saltells. És a dir, que als monjos no els interessaven tant els atacs als dominis com les vexacions de les quals eren víctimes directament fins que aquells no adquiriren, a partir de finals del mes de novembre, certa intensitat.
} 
dramatisme general del document i resultar, d'aquesta manera, més convincents.

Els monjos fan referència, en concret, a cinc estades de Guillem de Montcada al monestir entre Pasqua i Nadal: vuit dies abans de Sant Pere (21VI), per la fira de Sant Cugat (25-VII), la Nativitat de la Mare de Déu (8-IX), abans de la festa de Sant Andreu i la vigília de Sant Andreu (29-XI), a les quals caldria afegir-hi la de Ramon d'Oliv(...) i els seus cavallers la vigília i la festa de Santa Maria d'agost (14 i 15-VIII).

Guillem de Montcada no acudeix sol a Sant Cugat; l'acompanya sempre un nombre variable d'homes fidels, armats - cavallers i escuders (armigeros) $-{ }^{70}$ o inermes, amb els animals de transport (cavalls i ases). El poder de Guillem de Montcada apareix aquí amb tota la seva expressió. El nombre d'homes que acompanya el fill del senescal oscillla entre $20 \mathrm{i} 70 \mathrm{i}$ el nombre de bésties entre 12 i 40, però amb el temps tendeix a augmentar. El 21 de juny són 20 homes armats, entre cavallers i escuders. El 27 de juliol Guillem de Montcada acudeix a la fira de Sant Cugat i s'estatja al monestir amb un gran nombre de cavallers i d'altres homes (cum magna multitudine militum et aliorum hominum), en qualsevol cas prou gran com per haver escapat a la capacitat de quantificació dels monjos. La vigília de Santa Maria d'agost, Ramon d'Oliv(...), enviat pel Montcada, acudeix al monestir amb un nombre indeterminat de cavallers i 12 bésties, i s'hi està dos dies. Guillem de Montcada torna al monestir pel novembre, abans de Sant Andreu, amb 30 cavallers i molts altres homes i la vigília de Sant Andreu s'hi estatja amb 70 homes i 40 animals.

Observem que les estades es produeixen durant $\mathrm{o}$ amb posterioritat a les collites d'estiu i que el grup d'acompanyants de Guillem de Montcada tendeix a ser cada cop més nombrós. Inicialment aquest està constituït per la seva mainada de cavallers i homes armats, però posteriorment s'hi afegeixen un nombre indeterminat d'homes inermes, que no formen part de la seva mainada i que ni tan sols queda clar que siguin homes seus.

Tot i que després de Sant Andreu no consta cap altra estada al monestir, potser perquè les existències ja havíen començat a esgotar-se, l'activitat depredadora del Montcada i dels seus homes no s'atura aquí, sinó

${ }^{70}$ armiger significa escuder, però és difícil saber en la documentació d'aquesta època si és emprat en aquest sentit o genèricament per a indicar qualsevol jove, no armat cavaller, que acompanyava el seu senyor i el servia (Joan BASTARDES PARERA, Glossarium Mediae Latinitatis Cataloniae, Barcelona, Universitat de Barcelona, Escuela de Filologia del CSIC, 1963-1996, pp. 156-157). 
que es reprèn amb dos nous assalts al mas Saltells, relatats en la primera querimònia. El dia de Sant Esteve els homes de Guillem de Montcada anaren al mas Saltells i robaren 20 quarteres d'ordi i una part dels atuells de la casa. I dos dies més tard, pels Innocents, el fill del senescal tornà al mas i envià els seus cavallers i escuders, amb els cavalls, i altres homes -precisa la querimònia- de condició pagesa (et aliis rusticis), els quals feren nombroses destrosses, abocaren i s'emportaren el vi i robaren el blat que els monjos havien comprat.

Ultra els efectes devastadors d'aquestes darreres incursions, la preocupació per l'avituallament sembla presidir un bon nombre d'accions del Montcada, especialment les estades al monestir i el robatori d'importants reserves de blat del mas Saltells ${ }^{71}$. L'increment del nombre d'homes que acompanyen el fill del senescal en les seves estades al monestir i l'augment de la freqüència de les incursions als dominis a partir de la festa de Sant Andreu ${ }^{72}$ estarien apuntant cap a un agreugament de la crisi frumentària a les acaballes de la tardor $\mathrm{i}$ els inicis de l'hivern d'aquell any. És possible, en aquest context, que Guillem de Montcada hagués acabat arrossegant i vehiculant en contra de Sant Cugat un moviment de descontent popular, al qual podria respondre tant la presència d'aquests homes inermes poc definits, confosos entre els fidels del Montcada, com la participació activa de rustici en el darrer assalt del mas Saltells.

Finalment, els monjos denunciaren al comte que Guillem de Montcada havia convertit el monestir en el centre de la seva jurisdicció: durant les seves estades hi celebrava plets i vistes $i$, a més, afirmava tenir-hi guarda i batllia ${ }^{73}$.

La guarda i batllia era una institució, originàriament pública, relacionada amb l'exercici de la justícia sobre els homes lliures. Els alous

\footnotetext{
${ }^{71}$ Vegeu més amunt p. 862. MORETA, Malhechores-feudales..., p. 98-108, subratlla, per al cas de Castella, la relació existent a partir de mitjan segle XIII entre les crisis agràries i les malfetrias feudals. Segons aquest autor, els nobles castellans s'haurien llençat a la guerra i al pillatge per a compensar i paliar la disminució de les seves rendes i el deteriorament del seu nivell de vida en un context de caiguda de la producció agrària, alça dels preus i davaluacions monetàries.

${ }^{72}$ Vegeu taula I.

${ }^{73}$ Els termes guarda i batllia, tal i com apareixen en els Usatges [Usatge 120: In baiulia sive guarda, Joan BASTARDAS (Ed.), Usatges de Barcelona. El codi a mitjan segle XII, Barcelona, Fundació Noguera, 1984, p. 132] signifiquen protecció i tutela.
} 
posats sota la batllia del comte eren coneguts amb el nom de franqueses ${ }^{74}$. Entre 1151 i 1198 molts petits aloers posaren els seus béns i les seves persones sota la guarda i batllia del comte-rei o d'un orde militar a canvi del pagament d'un cens anual en espècie ${ }^{75}$. Seguint el seu exemple, alguns abats i priors posaren els seus monestirs i els seus honors sota la protecció del comte a canvi de petits pagaments regulars en espècie o bestiar obligats sobre les rendes del domini ${ }^{76}$. El comte-rei rebia els homes sota la seva batllia i es comprometia a defensar les seves persones i els seus béns «contra tot home 0 dona», es convertia en jutge dels plets que podien tenir els seus protegits $\mathrm{i}$ podia exigir-los estacament o ferma de dret. L'extensió de la institució de la guarda i batllia comtal és un factor important alhora d'explicar la proliferació de querimònies escrites d'origen pagès o monàstic a la segona meitat del segle XII.

La queixa dels monjos de Sant Cugat col·locada, deliberadament, al final del document, resulta reveladora dels objectius darrers de la querimònia. $\mathrm{Si}$ ja aleshores el monestir de Sant Cugat del Vallès estava sota la guarda i batllia del comte, la querimònia contindria implícit un greuge contra el poder per haver tolerat o negligit la intromissió baronial. Però, potser aquest document fou l'origen d'una sol-licitud, la que la comunitat de Sant Cugat adreçà al comte perquè acollís el monestir i els seus dominis sota la seva jurisdicció per tal que, en endavant, fets com els denunciats no es tornessin a produir.

\footnotetext{
${ }^{74} \mathrm{~A}$ la segona meitat del segle XI existien tres nuclis de franqueses al Vallès Oriental, al Maresme, i a les parròquies occidentals del territori de Barcelona i del pla del Llobregat. Cf. Josep MORAN I OCERINJAUREGUI; Montserrat BELTRAN I MORALES, Les franqueses del poble de les Corts, del segle IX al segle XVII, "El Pla de Barcelona i la seva història", Barcelona, Institut Municipal d'Història, 1984, pp. 27-35.

${ }^{75}$ Freedman, The Origins of Peasant Servitude, pp. 99-103.

${ }^{76}$ L'any 1178 Alfons I, a precs de Guillem, abat de Banyoles, i de Bernat, prior de Sant Marçal del Montseny, posà aquest priorat, tots els seus béns i tots els seus homes i dones, i de manera particular l'honor que aquest tenia a Vilassar i Argentona sota la seva guarda i protecció. Alfons I ordenà al seu veguer de Barcelona, al batlle de Vilamajor i als altres batlles que defensessin el prior i el seu honor com si es tractés de coses pròpies (BC, Arxiu, perg. 10141 [caixa 9], trasllat de 1291).
} 


\section{NOVA APROXIMACIÓ A LA DATACIÓ DEL DOCUMENT I RESOLUCIÓ DELS CONFLICTES}

Tot aquest conjunt de dades permeten proposar una seqüència per a les accions perpetrades per Guillem de Montcada i afinar encara més la datació del document. Si admetem que: a) els fets relatats en la primera i la darrera querimònia tingueren lloc coetàniament entre Pasqua i els Innocents -dates festives extremes dels dos relats-d'un mateix any i, per tant, formen part d'una mateixa escomesa dirigida per fill del Senescal contra el monestir, b) que en la memòria dels monjos redactors aquests fets, els quals motivaren la redacció del document, eren força recents puix que les dates extremes del calendari litúrgic que emmarquen les vexacions perpetrades pel Montcada dins del recinte monàstic, relatades a la darrera querimònia, eren proppassades ( $a$ transacta festivitate Paschali usque ad Natale Domini transactum), c) que d'acord amb l'acotació que hem proposat més amunt, la querimònia, que presenta una unitat i era adreçada a una única vista, fou escrita entre el 2 d'octubre del 1160 - data de la sentència pronunciada pel jutge Borrell de Girona en la causa sobre el castell de Sant Vicenç de Calders- i el 6 d'agost de 1162 - data de la mort de Ramon Berenguer IV_, podem concloure que els fets referits tingueren lloc durant l'any 1160 o durant el 1161 . Un petit detall permet excloure la primera possibilitat: l'any 1160 Nadal s'escaigué en diumenge. La primera querimònia relata que el segrest d'un noi que llaurava amb bous i altres dos que cavaven la vinya fou perpetrat per Bernat de Castlarí el dissabte (feria VI) abans de Nadal. El Nadal d'aquest any no podia escaure's en diumenge, perquè el dissabte hagués estat la vigilia Natalis, una de les diades assenyalades del calendari litúrgic. Per tant, si els referents temporals que aporta el document són correctes, tal com podem suposar del caràcter elaborat de la querimònia, podem afirmar que els fets relatats a la primera i cinquena querimònia tingueren lloc entre Pasqua i els Innocents de 1161 i que el document fou redactat segurament poc després d'aquesta data, en tot cas abans de la Pasqua de 1162, és a dir, entre el 29 de desembre de 1161 i el 7 d'abril de 1162 .

Si sumem els dotze episodis de la primera querimònia i les sis estades de Guillem de Montcada i dels seus homes al monestir, obtenim un total de 
divuit episodis ${ }^{77}$, set dels quals es concentren en menys d'un mes, entre el 29 de novembre i el 28 de desembre. La seqüència dels episodis datats revela que les incursions de Guillem de Montcada al monestir i als seus dominis havien anat esdevenint, a mesura que la tardor avançava, cada cop més freqüents, $\mathrm{i}$ arribaren a la seva màxima intensitat pels volts de Nadal. Hom comprèn, doncs, que, al final del mes de desembre, havent arribat a una situació insostenible, els monjos decidissin actuar. Primer intentaren una entesa dialogada amb el Montcada, utilitzant l'arma ideològica. Sortiren al seu encontre i li demanaren, invocant el nom de Déu, del màrtir Cugat i del comte, que aturés la persecutio, un mot que per sí mateix revela la percepció que els monjos tenien dels atacs com a part d'una campanya persistent i obsessiva dirigida contra el monestir. Ja hem vist que fracassaren en l'intent. Aleshores optaren per la via judicial: redactaren i enviaren al comte, segurament pocs dies després dels Innocents, aquesta querimònia. Si tenim en compte la freqüència de les incursions pels volts de Nadal, res fa suposar que l'episodi dels Innocents fos el darrer atac del Montcada contra el monestir. Més aviat cal pensar, inversament, que si aquest fou el darrer dels episodis relatats, és perquè la querimònia devia redactar-se tot seguit o no gaire després, segurament els darrers dies de l'any 1161 o els primers del mes de gener de 1162.

\footnotetext{
${ }^{77}$ Vegeu taula I.
} 
TAULA I

Els atacs de Guillem de Montcada: seqüència cronològica

(primera i cinquena querimònia)

\begin{tabular}{|c|c|c|c|}
\hline \multicolumn{4}{|c|}{ DWUA: } \\
\hline $\begin{array}{l}\text { Vuit dies abans de } \\
\text { Sant Pere }\end{array}$ & 21 juny & $\begin{array}{l}\text { Guillem de Montcada, els seus cavallers i } \\
\text { escuders }\end{array}$ & $\begin{array}{l}\text { Estada al mo- } \\
\text { nestir }\end{array}$ \\
\hline Sant Cugat & 25 juliol & $\begin{array}{l}\text { Guillem de Montcada amb un gran nombre } \\
\text { de cavallers i altres homes }\end{array}$ & $\begin{array}{l}\text { Estada al mo- } \\
\text { nestir }\end{array}$ \\
\hline $\begin{array}{l}\text { Assumpció de la } \\
\text { Mare de Déu }\end{array}$ & 14-15 agost & Ramon d'Oliv[...] i els seus cavallers & $\begin{array}{l}\text { Estada al mo- } \\
\text { nestir }\end{array}$ \\
\hline $\begin{array}{l}\text { Nativitat de la Ma- } \\
\text { re de Déu }\end{array}$ & 8 setembre & Guillem de Montcada & $\begin{array}{l}\text { Estada al mo- } \\
\text { nestir }\end{array}$ \\
\hline $\begin{array}{l}\text { Abans de la festa } \\
\text { de Sant Andreu }\end{array}$ & $\begin{array}{l}{[\ldots 9-28] \text { no- }} \\
\text { vembre }\end{array}$ & $\begin{array}{l}\text { Guillem de Montcada amb } 30 \text { cavallers i } \\
\text { altres }\end{array}$ & $\begin{array}{l}\text { Estada al mo- } \\
\text { nestir }\end{array}$ \\
\hline $\begin{array}{l}\text { Vigília de Sant An- } \\
\text { dreu }\end{array}$ & 29 novembre & Guillem de Montcada amb 70 homes & $\begin{array}{l}\text { Estada al mo- } \\
\text { nestir }\end{array}$ \\
\hline \multirow[t]{3}{*}{$\begin{array}{l}\text { Sant Pau de Nar- } \\
\text { bona }\end{array}$} & 11 desembre & Berenguer de Saltells, batlle & $\begin{array}{l}\text { Assalt del mas } \\
\text { Saltells }\end{array}$ \\
\hline & $\begin{array}{l}{[12-22] \text { desem- }} \\
\text { bre }\end{array}$ & Berenguer de Saltells, batlle & $\begin{array}{l}\text { Segrest d'un es- } \\
\text { clau sarraí del } \\
\text { mas de Pere } \\
\text { Guiribert }\end{array}$ \\
\hline & $\begin{array}{l}{[12-22] \text { desem- }} \\
\text { bre }\end{array}$ & Berenguer de Saltells, batlle & $\begin{array}{l}\text { Segrest d'un } \\
\text { home encadenat } \\
\text { d'un mas domi- } \\
\text { nicum de Sant } \\
\text { Cugat } \\
\end{array}$ \\
\hline $\begin{array}{l}\text { Dissabte abans de } \\
\text { Nadal }\end{array}$ & 23 desembre & $\begin{array}{l}\text { Bernat de Castlarí, per manament de B. de } \\
\text { Saltells }\end{array}$ & $\begin{array}{l}\text { Assalt del mas } \\
\text { Saltells }\end{array}$ \\
\hline Sant Esteve & 26 desembre & Homes de Guillem de Montcada & $\begin{array}{l}\text { Assalt del mas } \\
\text { Saltells }\end{array}$ \\
\hline Sants Innocents & 28 desembre & $\begin{array}{l}\text { Guillem de Montcada, els seus homes ar- } \\
\text { mats i altres, pagesos }\end{array}$ & $\begin{array}{l}\text { Encontre amb } \\
\text { els monjos da- } \\
\text { vant del mones- } \\
\text { tir. Assalt del } \\
\text { mas Saltells }\end{array}$ \\
\hline
\end{tabular}

${ }^{78}$ Segurament pocs dies abans de la festa de Sant Andreu; en tot cas mai abans del 9 de novembre, festa de la Passió del Senyor, una altra diada assenyalada del calendari litúrgic. 
És, doncs, força probable que aquest memorial de greuges redactat per la comunitat de Sant Cugat arribés a mans de Ramon Berenguer IV en els darrers mesos de la seva vida.

Tot i el caràcter unitari que, deliberadament, els monjos conferiren al document, les notícies posteriors evidencien que la resolució judicial i extra-judicial dels conflictes seguí en cada cas vies independents. Per al cas del plet sobre el castell de Sant Vicenç de Calders, l'únic dels quatre conflictes referits a la querimònia del qual coneixem la resolució, s'arribà a un acord extrajudicial, forçat pel refús de la justícia expressat per Berenguer d'Ollers després de la sentència de Borrell. Ambdues parts s'avingueren a acceptar el laude dels prohoms Guillem de Castellvell, Guillem de Papiol i Bertran de Vilalba, en mans dels quals dipositaren les penyores corresponents. Aquests arbitraren que l'abat $\mathrm{i}$ els monjos de Sant Cugat lliuressin a Berenguer d'Ollers i a la seva muller 20 morabatins i que aquests, a canvi, els hi definissin i evaqüessin a perpetuïtat el castell de Sant Vicenç. L'acte de definició i evacuació, que sembla haver posat fi al conflicte, copiada al Cartulari, porta data del 13 de setembre de $1163^{79}$.

De la resta de contenciosos i, en particular, del que enfrontà Sant Cugat amb Guillem de Montada, no ens n'ha pervingut cap notícia, el que contribueix a accentuar l'aïllament documental de la querimònia. Aquest silenci, però, pot ser particularment significatiu, si tenim en compte el protagonisme polític que el pare de Guillem, el senescal Guillem Ramon, tingué durant els primers anys del regnat d'Alfons I. Guillem Ramon acompanyà Ramon Berenguer IV en el seu viatge a Torí per a trobar-se amb l'emperador Frederic Barba-roja a Torí, el mes d'agost de 1162, en el curs del qual el comte morí. Durant la minoria d'Alfons el Cast, exercí la regència del regne fins a la seva mort, l'any $1173^{80}$.

Guillem Ramon de Montcada degué tenir un paper decisiu en l'aturada de l'escomesa de Guillem de Montcada contra els dominis del monestir i el restabliment de la pau, objectiu immediat de la querimònia de Sant Cugat. Però probablement la intervenció del Gran Senescal en el conflicte anà més enllà, afavorint una solució pactada del contenciós entre els Montcada i Sant Cugat que inclouria des del redreçament dels danys infringits fins a acords de

${ }^{79} \mathrm{ACA}, \mathrm{CSC}$, f. 103, doc. 351, Rius, III, pp. 215-216, doc. 1050.

${ }^{80}$ SHIDELER, The Montcadas, pp. 103-113. 
repartiment o delimitació de béns i drets. En aquest sentit, un document datat de l'any 27 del rei Lluís el Jove (24 juny de $1163-23$ juny de 1164 ) i copiat al Cartulari de Sant Cugat, podria tenir relació indirecta amb la fi dels contenciosos entre Sant Cugat i Guillem de Montcada ${ }^{81}$. Es tracta d'un conveni pel qual l'abat Ramon cedeix al senescal, al seu fill Guillem i a tots els seus descendents la fira del terme de Sant Cugat perquè la traslladin al terme de Montcada, a Guardiola, molt a prop del prat de Matabous. El monestir reté el dret de comprar el que li calgui sense pagar lleuda, costum ni cap usatge, i la desena part dels ingressos de la fira, llevat de les rendes de l'administració de justícia (placitis) que en endavant correspondran íntegrament als Montcada. Per aquesta donació i per altres feus que tenen pel monestir de Sant Cugat, Guillem Ramon i el seu fill es comprometen a ésserlos homes fidels i defensors de tot l'honor del monestir ${ }^{82}$. Tot i que el context específic d'aquest conveni se'ns escapa, és possible que Sant Cugat del Vallès acabés comprant la pau i la seguretat dels seus dominis mitjançant la cessió amb certes retencions de la fira, un dels elements més cobejats pels Montcada i que més maldecaps havia portat al monestir.

${ }^{81} \mathrm{D}$ 'acord amb la proposta d'Anscari $\mathrm{M}^{\mathrm{a}}$ MuNDÓ, El concili de Tarragona de 1180: dels anys dels reis francs als de l'Encarnació, "Analecta Sacra Tarraconensia", 67/1 (1994), pp. XXIII-XLIII.

82 “Ego quoque supradictus Guillelmus Raimundi Dapifer et filius meus Guillelmus de Monte Catano, propter hoc donum quod tu Raimundus abbas et monachi Sancti Cucuphatis superius nobis facitis et propter alios fevos quos de domo Sancti Cucuphatis habemus et tenemus, convenimus nos et successores nostri vobis et successoribus vestris esse fideles homines et esse defensores et adiutores de omni honore et rebus que domus Sancti Cucuphatis habet et in antea, Deo auxiliante, habuerit, per bonam et rectam fidem, sine engan, omni tempore" (ACA, CSC, f. 47, doc. 157; RIUS, III, pp. 214-215, núm. 1049). 


\section{EL DOCUMENT}

\section{s.d. [1161 desembre $29-1162$ abril 7]}

Relació de queixes que l'abat $i$ els monjos de Sant Cugat presenten al comte de Barcelona contra Guillem II de Montcada $i$ el seu batlle Berenguer de Saltells, Guillem III de Sant Martí, Ponç Guerau d'Olorda i Arnau de Ribes, i Arnau de Benages, Berenguer d'Ollers i Bernat de Castellnou.

A. ACA, Monacals, pergamins sense inventariar ${ }^{2}, 190 \times 130 \mathrm{~mm}$.

[1.1] Sancti Cucuphatis abbas et monachi sui clamores domino comitis deponunt de Guilelmo de Monte Cata ac suis hominibus quod mansum de Saltellis vastantes dextruxerunt. Primum namque viam fontis, unde per totum tempus mansus ille aquam habuit, clauserunt. Oves quoque domine illius mansi XXVI Guilelmus de Monte Cata auferre fecit. Frumentum quod ipsa domina comendaverat Raimundo de Cerdaniola XXII quarteres rapere fecit.

[1.2] In alia vero die, veniens ad mansum de Saltellis, eam dominam minatus fuit capere et ardere nisi mansum relinqueret, et quoscumque homines vel feminas in manso invenerit pedes atque aures truncare, oculos eruere minatus fuit. Idcirco nullus est ausus ibi stare.

[1.3] Item in alia vice veniens cum suis hominibus ad mansum Petri de Sales, qui est dominicus Sancti Cucuphatis, mansum frangendo, multum averem ab ipso manso trahere fecit, quod avere numquam abbati reddere noluit.

[1.4] In die autem alia quendam hominem Sancti Cucuphatis, scilicet Bernardum de Pedrehcs, sepedictus Guilelmus capiens illum in foveam eiecit. Abbas vero per suos monachos, per vocem domini comitis, Guilelmo de Monte Cata hominem quesivit, quod auscultare noluit, sed illum redimere fecit $\mathrm{XX}$ quarteras frumenti et $\mathrm{XX}$ quarteras ordei et $\mathrm{XX}$ quarteras espelte.

'El document fou redactat, molt probablement, poc després del dia dels Innocents ( $28 \mathrm{de}$ desembre) del 1161, data del darrer dels episodis relatats a la primera querimònia, en qualsevol cas abans de la Pasqua (8 d'abril) del 1162 . Vegeu més amunt.

${ }^{2}$ Numeració provisional: A-198. 
[1.5] Item Guilelmus de Monte Cata veniens ad dominium Sancti Cucuphatis, quod dominium vocatur Bellum Vicinum, quod etiam ${ }^{3}$ Borrellus comes Barchinonensis ob remedium animae suae suorumque parentum monasterio Sancti Cucuphatis obtulit ${ }^{4}$, et ibi chestam duas vices vel tres in anno facit ad dominicos homines Sancti Cucuphatis qui per illum nichil facere habent.

[1.6] Preterea ille Guilelmus et sui homines venientes ad dominicaturam Sancti Cucuphatis de Ripolleto, ortos et pomeria frangendo, fructus colligentes ducunt secum, et si ferragens in supradictis ortis invenerint, devastando secantes eas portant.

[1.7] In die vero Innocentum Guilelmus de Monte Cata transiens per monasterium, monachi, exientes ad illum, humiliter per vocem omnipotentis Dei et beati Cucuphatis et per vocem domini comitis rogaverunt eum ut ab hac persecutione cessaret. Quod ipse audiens in despectum habuit, et dixit illis male atque durissime quia nec per comite neque per episcopum in omnibus diebus vitae suae non cessaret, secundum suum posse, ab hac persecutione. Et in illa die ad vesperum, veniens ad mansum de Saltellis, misit ibi suos milites et equos cum armigeris et aliis rusticis, qui diripientes subverterunt omne suppellectile domus et duodecim vasa [vina]rium?, columbaria vero destruxerunt, vinum quoque quod erat in tribus vasis bibentes, fundentes, portantes etiam ${ }^{8}$, et nostrum agrarium et aliud quod emptum habebamus [diri]perunt ${ }^{9}$.

[1.8] In Adventu Domini per diem festum sancti Pauli, veniens Berengarius de Saltels, baiulus Guilelmi de Monte Cata, ad mansum de Saltels, et educens ensem minatus est occidere dominam. Illa vero perterrita fugiit. Supradictus namque Berengarius honorem Sancti Cucuphatis quem huc usque tenuit per abbatem Sancti Cucuphatis, modo vendicat sibi pro suo alodio et domini sui.

[1.9] Iste vero Berengarius in alia die venit ad mansum Petri Guiriberti, qui mansus est alaudium Sancti Cucuphatis, frangendo illum, sarracenum unum ex ipso manso rapuit, quem per abbatem vel suos monachos reddere noluit usque quo Petrus Guiriberti, qui est dominicus homo Sancti Cucuphatis, illum redemit ab ipso Berengario.

\footnotetext{
${ }^{3}$ e caudada.

${ }^{4} \mathrm{La}$ donació a la qual fa referència la querimònia podria ser l'acte de cessió al monestir d'un alou situat a Reixac que efectuà el comte Borrell el 10 de març de 988 (ACA, CSC, f. 71v, doc. 280, RiUS, I, pp. 181-183, núm. 217).

${ }^{5}$ male atque durissime interlineat.

${ }^{6}$ diebus interlineat.

${ }^{7}$ Raspat.

${ }^{8} \mathrm{e}$ caudada.

${ }^{9}$ Raspat.
} 
[1.10] In alia vero die Berengarius de Saltels ad mansum dominicum Sancti Cucuphatis, qui mansus est in bosco, veniens, frangendo illum, unum hominem vinctum et oves et capras inde traxit. Hominem vero in foveam eiecit, quem vero abbas et sui monachi Guilelmo de Monte Cata et Berengario de Saltels, suo baiulo, quesierunt, quem illis nolentes reddere, hominem coegerunt ut se redimeret.

[1.11] Feriam VIa ante Natale Domini veniens Bernardus de Castlarino mandamento Berengarii de Saltels ad mansum de Saltels, inveniendo ibi puerum arantem cum bobus, capto illo cum aliis duobus fodientes in vineam ab ipso Bernardo, misit eos in tavegam, quos adhuc retinet. Quod videns, domina mansi fugiit ad monasterium.

[1.12] In die sancti Stephani homines Guilelmi de Monte Cata venientes ad iamdictum mansum, fodiendo illum, XX quarteras ordei inde traxerunt. Ianuas vero et hostia domorum et omnia vascula domus fregerunt atque portaverunt, seras quoque portarum extrahentes detulerunt.

[2] Item Sancti Cucuphatis abbas et monachi sui querimoniam deponunt de Guilelmo Sancti Martini. Venit autem Guilelmus Sancti Martini ad dominicaturam Castri Felicis, quam comes Barchinonensis Sancto Cucuphati dedit ${ }^{10}$ picem $^{11}$ invenit ibi quem Sancti Cucuphatis baiulus in die Natalis Domini mitere volebat abbati et monachis Sancti Cucuphatis. Quem picem ${ }^{12}$ Guilelmus Sancti Martini videns baiulo abstulit. Et confestim per omnes mansos ${ }^{13}$ iamdictae dominicaturae cum suis baiulis iens, frangendo mansos, abstulit inde bonas singulas pernas porcorum, et perne fuerunt VIIem. In alia vero die, suos baiulos mittens ad dominicaturam de Torres Bezces, III mansos ibi frangere fecit et inde guadengias et exadas portaverunt.

[3] Item conqueritur abbas Sancti Cucuphatis et sui monachi super Pontio Geraldi de Olorda atque Arnallo de Ripis. Umbertus vero de Cervilione misit in pignora Geraldo Gombaldi de Olorda, patri supradicti Poncii Geraldi, honorem quem ipse Umbertus habebat in Galechs pro CL solidos de plata a penso. Postea vero iamdictus Umbertus in suo testamento domui Sancti Cucuphatis dimisit supradictum honorem, tali modo ut abbas Sancti Cucuphatis vel sui monachi a predicto Geraldo

\footnotetext{
${ }^{10} \mathrm{~L}$ 'alou de Castelldefels, dins del terme del castell d'Eramprunyà, fou confirmat al monestir pels comtes Ramon Borrell i Ermessenda el 29 d'abril de 1011. En el document de reparatio, copiat al Cartulari, es diu que l'alou fou donat a Sant Cugat pels comtes Borrell i Letgarda "et eiusdem cartula fuit perdita per incuriam et incauta custodia, et post modum minime fuit inventa" (ACA, CSC, f. 268, doc. 831, RIUS, II, pp. 80-81, núm. 436).

"picem per piscem.

${ }^{12}$ picem per piscem.

${ }^{13}$ mansos interlineat.
} 
Gombaldi vel a filiis eius redimederent prescriptum honorem. R. vero abbas Sancti Cucuphatis vel sui monachi sepedictum honorem ab ipso Pontio Geraldi vel Arnallo de Ripis redimere multociens voluerunt, et illi prescriptum avere recuperare noluerunt neque honorem persolvere.

[4] Iam olim multociens Raimundus, Sancti Cucuphatis abbas, et sui monachi domino comiti Barchinonensi clamorem deposuerunt ${ }^{14}$ magnum super Arnallo de Benages et Berengario de Olers et Bernardo de Castro Novo. Qui Arnallus de Benages et Berengarius de Olers eis quoddam castrum Sancti Vincencii iniuste auferebant et Bernardus de Castro Novo similiter decimum de Rafegera illis iniuste auferebat. Quapropter domnus comes illos omnes ad curiam suam convocavit ut directum ibi domui Sancti Cucuphatis facerent. Convocatisque illis, scilicet Arnallus de Benages atque Bernardus de Castro Novo ad curiam comitis devenerunt. Berengarius vero de Olers venire noluit. Ibique vero, in presentia domini comitis, abbas et sui monachi cum predictis Arnallo atque Bernardo placitaverunt. Auditisque ab utraque parte rationibus et carta Sancti Cucuphatis ibi ostensa et perlecta, domnus comes cum sua curia omnem illum honorem cognovit esse directum Sancti Cucuphatis. Ideoque domnus comes verbo, in presentia illorum, predictum honorem imparavit et abbati et suis monachis deliberavit, et etiam suo baiulo, scilicet Berengario de Avinione, mandavit ut imparando eis ex sua parte deliberaret. Quod etiam ${ }^{15}$ Berengarius baiulus adimplevit. Et confestim predictus Bernardus de Castro Novo decimum de Rafegera abbati et monachis desemparavit et adhuc iniuste retinet. Berengarius vero de Olers, cum audisset haec omnia, cartam se habere dixit cum qua omnem predictum honorem sibi et aliis prescriptis directo recuperaret. Quo audito, abbas et sui monachi ad comitem euntes hoc dictum predicti Berengarii sibi narraverunt. Comes vero, hoc audito, abbati et monachis mandavit ut cartam illorum et cartam Berengarii de Olers in potestate Borrelli, iudicis Ierunde, devenirent, ut ipse inter illos discerneret. Quod ita totum in aecclesia Sancti Genesii de Martorello completum fuit. Et sicut ille Borrellus et in illa aeclesia iudicavit, iudicium quod ipse ore suo dedit, scriptum est manuque sua aliisque testibus ibi assistentibus firmatum. Berengarius namque de Olers, audito hoc iudicio, consilio et defensione Guilelmi de Papiol, directum non esse ${ }^{16}$ nec iudicium archiepiscopi neque aliorum hominum neque curie domini comitis audire dixit. Sed ad castrum Sancti Vincentii pergens, desemparando illud, oves nostras ibi occidens, agnos et caseos rapiens, aratra

${ }^{14}$ runt interlineat.

${ }^{15} \mathrm{e}$ caudada.

${ }^{16}$ Les dues e caudades. 
frangendo, agrarium terrae sibi portans, etiam ${ }^{17}$ monachos vel homines quoscumque ibi inveniret minatus est debilitare atque occidere.

[5] Super haec omnia, quod magnum nobis grave est, predictus Guilelmus de Munt Cata venit in nostro monasterio per malum usaticum prandere et ospitare, et, ut vere credatis, a transacta festivitate Paschali usque ad Natale Domini transactum quantas vices venerit monstramus vobis: VIII dies ante festum sancti Petri stetit in nostro monasterio cum XXti infra milites et armigeros. Venit ad firam Sancti Cucuphatis cum magna multitudine militum et aliorum hominum, et stetit in domo nostra cum omnibus predictis. In vigilia sanctae Mariae augusti misit nobis Raimundum de Oliv[...cum $]^{18}$ suis militibus et cum XIIcim bestiis, et steterunt ibi IIobus diebus. Predictus Guilelmus stetit nobiscum in die sanctae Mariae septembris. Iterum venit in nostro monasterio ante festum sancti Andreae et stetit ibi cum XXXa militibus et aliis multis. Venit etiam ${ }^{19}$ in vigilia sancti Andreae et ospitatus est nobiscum cum XL bestiis et cum LXXa hominibus. In crastinum autem, cum recessisset a nobis, minatus est nobis et nostris hominibus magnum malum et deshonorem facere. Ibi mandat suos placitos et suas vistas et, quod ${ }^{00}$ domino comiti Barchinonensi peius debet esse ${ }^{21}$, dicit ibi se habere guardam et baiuliam.

\section{RÉSUMÉ}

Entre la fin de l'année 1161 et les premiers mois de 1162, les moines de labbaye bénédictine de Sant Cugat del Vallès, près de Barcelone, rédigèrent un mémoire de plaintes, adressé au comte Ramon Berenguer IV, dans lequel ils dénonçaient les actes de violence perpétrés contre les hommes et les propriétés du monastère par divers nobles, parmi lesquels se détache tout particulièrement Guillem de Montcada, fils du sénéchal Guillem Ramon. Le résultat fut une des querimoniae (chartes de doléances) les plus longues et les plus originales qui nous soient parvenues. Rédigée dans un latin correct et un style soigné, cette production élaborée du scriptorium monastique constitue un témoignage littéraire unique de la manière par laquelle, dans la Catalogne de la seconde moitié du XIIe siècle, la seigneurie arbitraire des barons se fit sentir sur la paysannerie. Cet article comprend la présentation, létude et l'édition de cette source, jusqu'à aujourd'hui pratiquement inconnue de l'historiographie, du fait que,

\footnotetext{
${ }^{17} \mathrm{e}$ caudada.

${ }^{18}$ Espai il $\cdot$ legible de quatre o cinc lletres.

${ }^{19} \mathrm{e}$ caudada.

${ }^{20}$ Segueix un espai de dues lletres raspat.

${ }^{21}$ Les dues e caudades.
} 
comme d'autres anciens documents non datés, elle avait été déclassée. On identifie les personnages du texte, on reconstruit la suite des événements, on essaie de dater le document, de cerner les mobiles qui portèrent les moines à le rédiger et les objectifs ultimes que ceux-ci poursuivaient.

\section{SUMMARY}

Sometime during the closing days of 1161 or the beginning of 1162 , the monks of the Benedictine abbey of Sant Cugat del Vallès, near Barcelona, composed a memorial of complaint addressed to Count Ramon Berenguer IV. In it they denounced acts of violence committed against the men and property of the monastery by various nobles, most notably Guillem de Moncada, son of the seneschal, Guillem Ramon. This memorial is one of the most detailed and original querimoniae to have survived. Written in correct Latin and with a certain attention to style, this product of the monastic scriptorium is a unique literary witness to the way in which the arbitrary lordship of the barons was experienced by the peasantry in twelfth-century Catalonia. This article offers an introduction, historical study, and edition of this source, to date almost entirely overlooked by scholars because it remained uncatalogued along with other undated documents from the monastery's archive. Persons named in the text are identified, the sequence of events is reconstructed, and suggestions are offered as to the date of the document, the reasons that led the monks to redact it, and their less obvious motivations. 


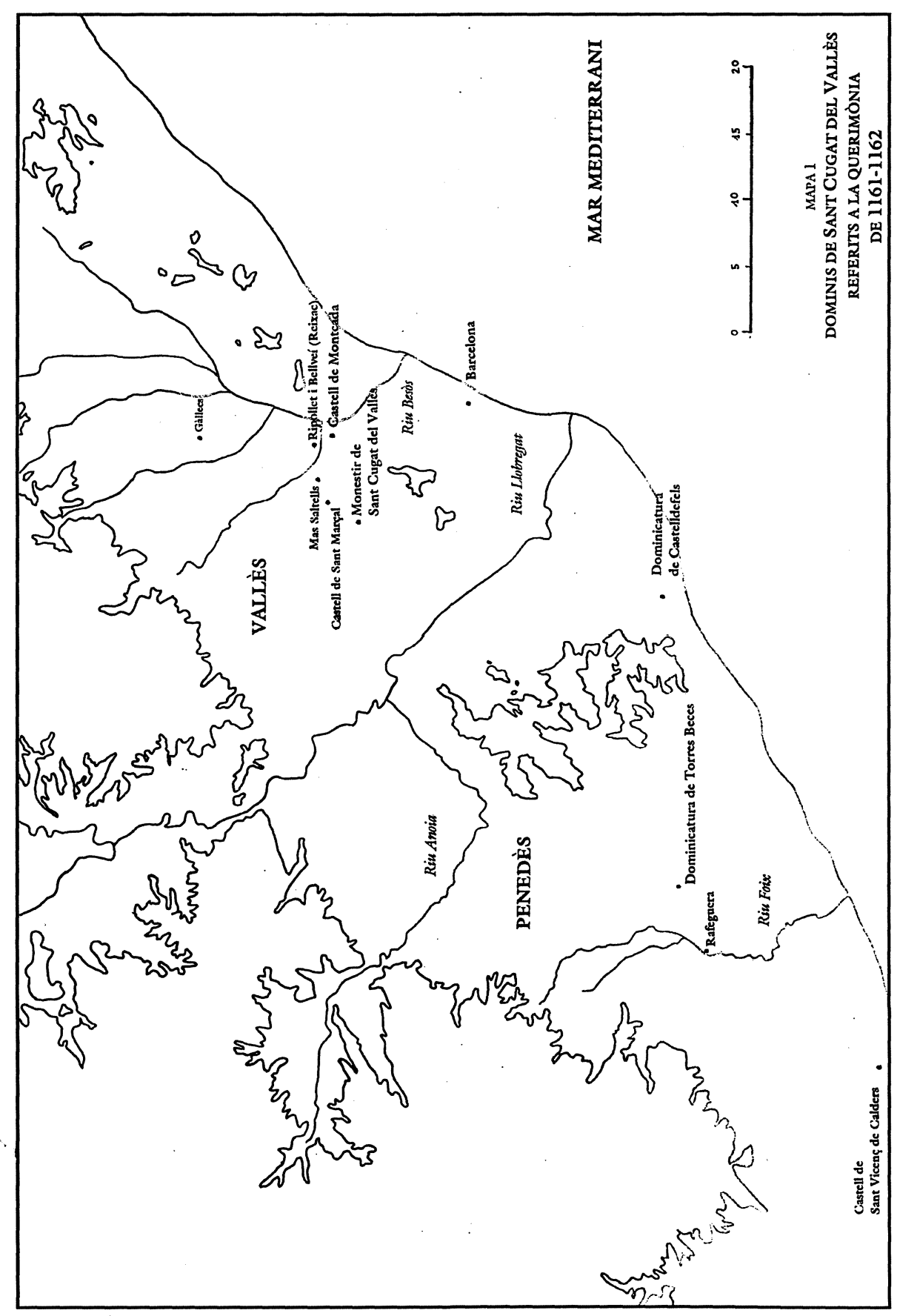




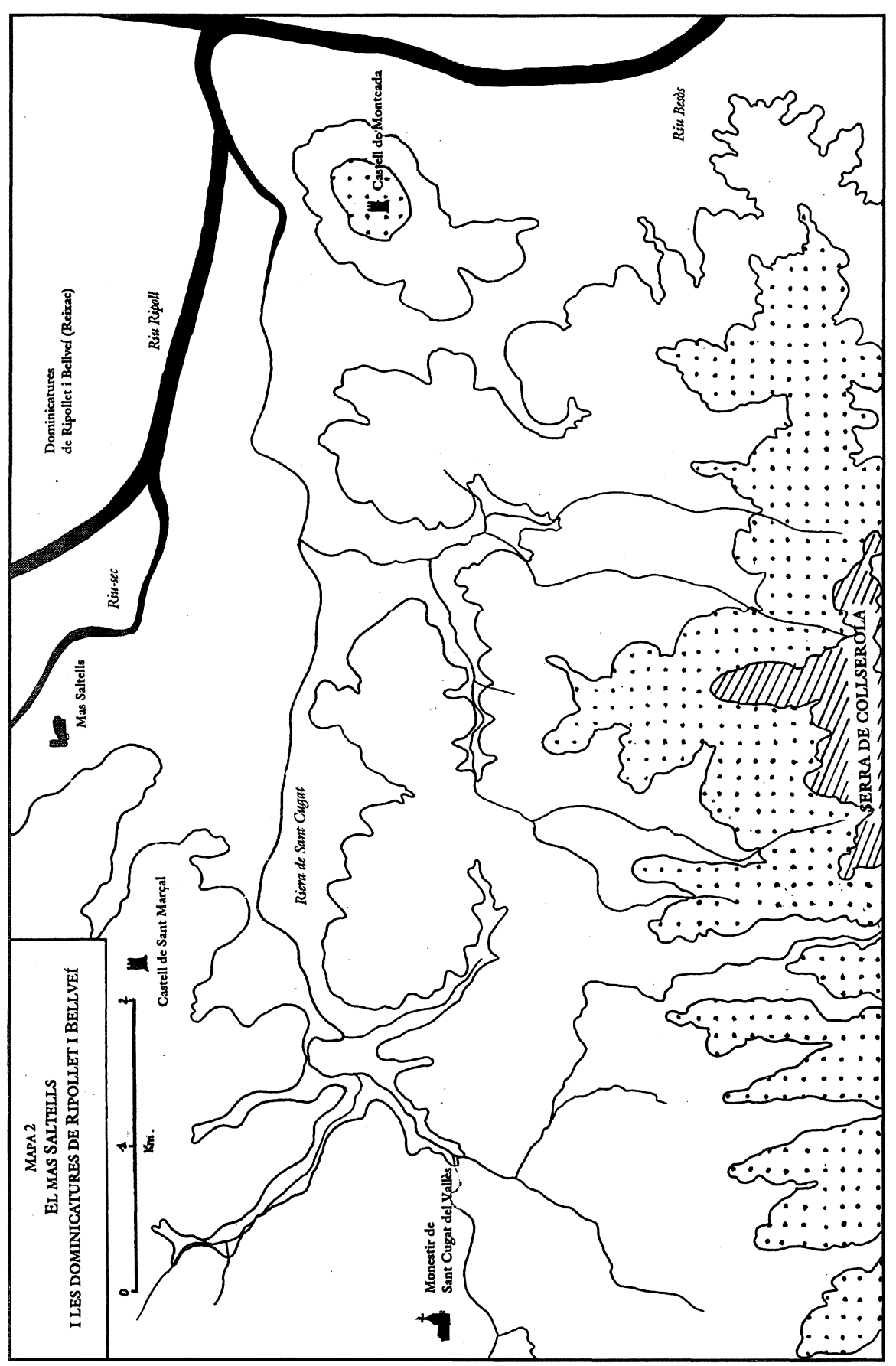

